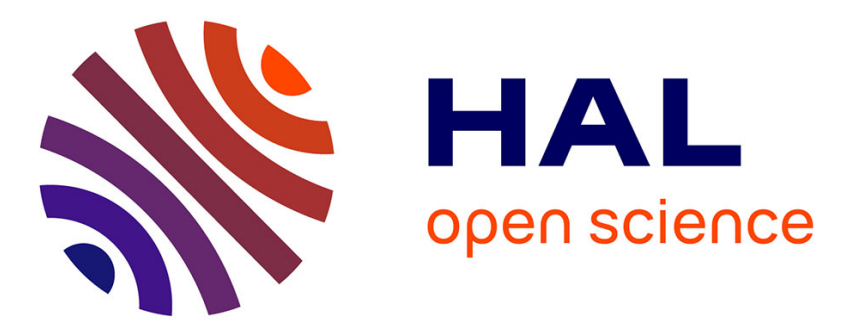

\title{
Immigrants' Wage Performance in a Routine Biased Technological Change Era: France 1994-2012
}

Eva Moreno-Galbis, Jérémy Tanguy, Ahmed Tritah, Catherine Laffineur

\section{To cite this version:}

Eva Moreno-Galbis, Jérémy Tanguy, Ahmed Tritah, Catherine Laffineur. Immigrants' Wage Performance in a Routine Biased Technological Change Era: France 1994-2012. Industrial Relations, 2019, 58 (4), pp.623-673. 10.1111/irel.12245 . hal-02349455

\section{HAL Id: hal-02349455 \\ https://hal.science/hal-02349455}

Submitted on 6 Feb 2020

HAL is a multi-disciplinary open access archive for the deposit and dissemination of scientific research documents, whether they are published or not. The documents may come from teaching and research institutions in France or abroad, or from public or private research centers.
L'archive ouverte pluridisciplinaire HAL, est destinée au dépôt et à la diffusion de documents scientifiques de niveau recherche, publiés ou non, émanant des établissements d'enseignement et de recherche français ou étrangers, des laboratoires publics ou privés. 


\title{
Immigrants' Wage Performance in a Routine Biased
}

\section{Technological Change Era: France 1994-2012}

\author{
Eva Moreno-Galbis* \\ Ahmed Tritah
}

\author{
Jeremy Tanguy ${ }^{\dagger}$ \\ Catherine Laffineur ${ }^{\S}$
}

July 2019

\begin{abstract}
Over the period 1994-2012, immigrants' wage growth in France outperformed that of natives. We investigate to what extent changes in task-specific returns to skills contributed to this wage dynamics differential through two channels: different changes in the valuation of skills (price effect) and different occupational sorting (quantity effect). We find that the wage growth premium of immigrants is mainly explained by the progressive reallocation of immigrants towards tasks whose returns increase over time. Immigrants seem to have taken advantage of labor demand restructuring driven by globalization and technological changes.
\end{abstract}

JEL Codes: J15, J24, J31, J61, O33

Keywords: Wage dynamics, tasks, immigrants, skills

*Corresponding author Aix-Marseille Univ., CNRS, EHESS, Centrale Marseille, IRD, AMSE, Marseille, France. Junior member of the Institut Universitaire de France. Email: eva.moreno-galbis@univ-amu.fr. Address: AMSE, Château de Lafarge, Route des Milles, 13290 Les Milles, France. Tel: +33442935960.

†University Savoie Mont Blanc, IREGE. Email : jeremy.tanguy@univ-smb.fr

‡Le Mans University, GAINS-TEPP, Email: ahmed.tritah@univ-lemans.fr

§University of Nice Sophia Antipolis, GREDEG. Email: catherine.laffineur@unice.fr

Eva Moreno Galbis acknowledges financial support from the Institut Universitaire de France and the French National Research Agency Grant ANR-17EURE-0020 


\section{Introduction}

Immigrants are a major workforce component and the main source of workforce growth in most developed countries. Not surprisingly, therefore, immigration and immigrants are at the forefront of wide-ranging policy debates. One central and often contentious issue is the extent to which immigrants are successful in their host countries' societies, of paramount importance in designing sustainable migration policies. This success depends largely on immigrants' labor market integration, mainly determined by their skills and how these are valued in their host country labor markets. In this paper, we analyze how the relative wage performance of immigrants has evolved in France over recent decades in relation to labor market changes (i.e. labor demand shifts and variation in returns to skills).

Immigrants' relative wage performance and wage dynamics are widely documented in the literature. Three factors are traditionally put forward to explain wage differences between immigrants and natives. A first factor is human capital in a broad sense, i.e. including schooling, experience and language skills (see Boudarbat and Lemieux (2014), Algan et al. (2010), Card (2005), Kee (1995) or Katz and Murphy (1992)). ${ }^{1}$ A second factor refers to differences in reservation wages between natives and immigrants, which put immigrants in a lower bargaining position compared to natives when they negotiate their wages with employers (see Nanos and Schluter (2014) for Germany, Moreno-Galbis and Tritah (2016) for the EU, Gonzalez and Ortega (2011) for Spain). A third important factor is discrimination (see Algan et al. (2010), Card (2005) or Kee (1995)).

Over recent decades, globalization, technological innovations, and other structural changes have induced both labor demand shifts and changes in returns to skills. This process has changed workers' occupational choices, i.e. workers are likely to have moved towards occupations requiring skills that offer increased returns. Beyond the traditional factors outlined in the literature, we expect changes in returns to skills and the ensuing changes in occupational choices to influence how the immigrant-native wage gap evolves over time. The objective of this paper is to assess the contribution of these two factors to the relative wage performance of immigrants and natives in France since the early 1990s.

Immigrants' and natives' wage performance are briefly summarized in Figure 1. Based on the French Labor Force Survey, we ranked occupations in ascending order according to the median wage paid in each occupation to form a ladder of 20 equal-sized (i.e. vigintiles) occupational employment groups. ${ }^{2}$ The left-hand panel of Figure 1 displays yearly average employment growth and the right-hand panel yearly average wage growth, both over that same skill ladder (i.e. wage ladder). We can see that immigrants' yearly wage growth out-performed that of natives over the whole occupational wage distribution, and particularly at the bottom of the distribution, where the annual difference in wage growth is around one percentage point. ${ }^{3}$ At the top of the skill distribution, the yearly difference

\footnotetext{
${ }^{1}$ The debate is centered on the role of the weighting of immigrants' different countries of origin and on changes in traditionalmeasures of skillsas wellas their portability. On theotherhand, the debatealsofocuses on the relative deterioration of immigrants' labor market outcomes upon arrival in the host country (Borjas (1995), Friedberg (2000), Card (2005) or Dustmann, Frattini, and Preston (2013)), as well as on the progressive convergence of immigrants' wages to those of natives with years of residence in the host country (see Chiswick (1978), Borjas (1994) or Borjas (1999) for the US, Chiswick, Lee, and Miller (2005) for Australia,FriedbergandHunt(1995)for Israel or Lam and Liu (2002) for Hong Kong).

${ }^{2}$ Following Autor and Handel (2013) this grouping can be viewed as a skill ladder.

${ }^{3}$ The divergent wage dynamics by nativity group is confirmed when estimating a quadratic equation relating $(\log )$ wage changes to initial wages.
} 
in wage growth is around 0.5 percentage point in favor of immigrants. ${ }^{4}$ Note that this higher wage growth of immigrants is robust to changes in population composition in terms of age, education, and length of residence 5 (see Figure 8 in Appendix C.1). The pattern of immigrants' employment across the occupational wage distribution in France is unusual, contrasting sharply with that observed in the US. In particular, Basso, Peri, and Rahman (2017) show a sharp increase in the share of immigrants at the lower end, with a decrease at the upper end, and thus a larger immigrant-native wage gap.

\section{INSERT FIGURE 1}

What explains the relatively good wage dynamics of immigrants in France over the period? We go beyond traditional factors studied in the literature and investigate the role of differences in workers' (unobserved) relative skill endowments, which we proxy using the task content of occupations. Considering occupations and their task content in the migration literature is relatively recent. According to the seminal Roy (1951) model, occupational specialization is due to workers' self-selection based on comparative advantages. Following that line of inquiry, Peri and Sparber (2011a), Peri and Sparber (2011b), Peri and Sparber (2009), Amuedo-Dorantes and De La Rica (2011), D'Amuri and Peri (2014) or Basso, Peri, and Rahman (2017) underline that natives and immigrants differ in their relative skill endowments. In these studies, immigrants' and natives' unobserved skill endowments are assessed according to the task requirements of occupations. A similar approach is applied by Warman and Worswick (2015) to the Canadian case to explain why rising education levels of immigrants during the 1990s did not lead to a large improvement in immigrants' earnings. In Imai, Stacey, and Warman (2019), the authors also use tasks to proxy skill requirements in pre- and post-immigration occupations and evaluate the returns to these skills through immigrants' weekly earnings. Adsera and Ferrer (2014) analyze the skill assimilation trajectory of immigrant women in Canada (particularly women graduates) using occupational tasks as skill proxies. Recently, Yamaguchi (2018) focuses on gender issues too, arguing that workers accumulate skills with experience of a task requiring particular skills.

We follow a similar line of inquiry in our paper. ${ }^{6}$ We assume that to perform the occupation-specific set of tasks, workers need a bundle of different skills whose importance depends on task type. Therefore, both the nature of the within-occupation tasks performed and the within- and between-occupation wage changes provide useful information about workers' skill endowments. Since workers in different occupations perform different tasks requiring different types and levels of skills, we can relate differences in task specialization to differences in skill endowments. Thus, immigrants and natives may have different skill endowments if they are employed in occupations with different task content. ${ }^{7}$

\footnotetext{
${ }^{4}$ This finding is consistent with Manacorda, Manning, and Wadsworth (2012) who, working with UK data, also show evidence of convergence in wages of immigrants and natives between 1973 and 2007.

${ }^{5}$ Unfortunately, our database does not contain information on language proficiency. Consistent with the findings of Lewis (2013), we proxy this variable by years of residence in the host country.

${ }^{6}$ This is also similar to the employer- or occupation-specific skill-weighted approach proposed by Lazear (2009) to study wage and employment mobility

${ }^{7}$ A major limitation of this migration literature placing occupations and their task content at the heart of economic analysis is that the task content of occupations is assumed time-constant. This assumption is pre-determined by the data sources used (such as $\mathrm{O}^{*} \mathrm{NET}$ ). While we acknowledge this limitation, the time-constant task composition of occupations affects both natives and immigrants. Since we are analyzing the wage dynamics differential between the two nativity groups, this data limitation should be less problematic.
} 
Immigrant job specialization may therefore explain certain changes in returns to skills relative to natives. In this setting, the same set of skills may be differently rewarded across occupations depending on their task composition. Moreover, changes in returns to skills (or changes in task prices) will affect wage changes both within and across occupations (Acemoglu and Autor, 2011). For instance, the premium on cognitive skills is lower in heavily manual occupations (e.g. movers) than in occupations involving more abstract tasks (e.g. actuaries). An increase in returns to cognitive skills is expected to have a greater impact in the latter occupations, increasing wage dispersion within occupations (between a good and a mediocre actuary) and also across occupations (between an average actuary and an average mover).

The contribution of our paper to the literature is threefold. First, while most of the literature focuses on the effect of immigration on natives' wages and occupations (see among others Peri and Sparber (2009), Amuedo-Dorantes and De La Rica (2011), D’Amuri and Peri. (2014) or Basso, Peri, and Rahman (2017)), we analyze immigrants' labor market performance and how changes in task prices affect this performance, an aspect seldom considered (see however the papers by Warman and Worswick (2015), Imai, Stacey, and Warman (2019) or Lubotsky (2011)). We offer a more nuanced view: by characterizing changes in returns on different tasks at different positions in the wage distribution, we show that immigrants tend to take advantage of changes in the wage structure. Second, we estimate changes in occupation-specific returns to skills and correlate these changes with immigrants' and natives' occupational choices, drawing conclusions on the evolution of their relative skill endowments. This is a clear departure from the existing literature. Yamaguchi (2018), Warman and Worswick (2015) or Imai, Stacey, and Warman (2019) also analyze changes in returns to skills but do not compute any resulting occupational changes. Adsera and Ferrer (2014) analyze immigrant women's occupational choices but not how returns to skills impact these choices. Third, not only do we explore the wage dynamics of the aggregate pool of immigrants and natives to isolate the effect of price changes on wages, but we also propose an original approach based on residual wages combined with a reweighting approach at the occupation level to control for factors that affect wage changes, such as country of origin, education, age, years since arrival, and sectoral distribution.

Our data source is the yearly French Labor Force Survey (LFS) between 1994 and 2012. In the first stage of our analysis, we estimate the price effect. Given a set of individual characteristics (age, education and length of residence), individuals located at the same position (i.e. decile) in the residual occupational wage distribution at different times are likely to have similar skills. Therefore, we can link wage changes over time in occupationspecific wage deciles to changes in occupation-specific returns to skills. Keeping the population's skill composition constant, this allows us to estimate a price effect not greatly contaminated by changes in population composition within an occupation. Then, we analyze what part of the price effect can be attributed to specific tasks. ${ }^{8}$

In a second stage, we relax the assumption of constant skill distribution and analyze how it evolved differently for immigrants and natives between 1994 and 2012, terming this the quantity effect. To do so, we rely on an

\footnotetext{
${ }^{8}$ We do so under the assumption that the task content of occupations can be related to workers' skill endowments. For instance, an occupation scoring high in the index of non-routine abstract tasks will require relatively more non-routine abstract skills (such as analytical or managerial skills) than occupations with a lower score.
} 
occupational choice model and estimate how immigrants' and natives' occupational choices reacted to the previously estimated price effects. In addition, we relate immigrants' and natives' distribution across occupations to occupational task content. ${ }^{9}$ The pattern of immigrants' and natives' occupational distribution allows us to characterize changes in task specialization that drive immigrants' and natives' relative wage performance over time.

We show that immigrants' wage growth performance over the period is essentially due to their occupational employment dynamics (i.e. quantity effect) rather than to changes in the value of their skills (i.e. price effect). This suggests that the comparative advantage of the two nativity groups shifted over the period. Relative to natives, immigrants gained comparative advantage as they moved up the skill ladder away from manual and routine tasks towards better-paid analytical and abstract tasks at a much faster rate than natives. This pattern is in sharp contrast to that documented for the US (see for example Basso, Peri, and Rahman (2017)), but more in line with the pattern documented for immigrant women in Canada (see Adsera and Ferrer (2014)).

The rest of the paper is organized as follows. In section 2 we present the data. In section 3 we provide supporting evidence. In section 4 we propose a conceptual setup to derive an empirical measure of the price effect and define the quantity effect. We describe the econometric approach and present the main results in section 5 , concluding in section 6. Additional results are presented in an extended appendix.

\section{Data}

\subsection{French Labor Force Survey}

The French Labor Force Survey (LFS) was established as an annual survey in 1982. Redesigned in 2003, it is now a continuous survey providing quarterly data on private households in mainland France. Participation is compulsory, with all household members older than 15 surveyed. The LFS provides detailed information on respondent characteristics, in particular on country of birth, which we use to distinguish natives from immigrants. ${ }^{10}$

The main topics of interest to us covered by the LFS concern employment, unemployment, hours of work, wages, length of employment and unemployment, industry, occupation, job status, education/qualification. There is little information on employers, the worker simply indicating approximate employer size by choosing from a list of sizeintervals in the questionnaire. Moreover, information on this variable is incomplete for some years. Information on occupations is available from a four-digit detailed list of occupations such as "gardener", "messenger", "clerk in banking activities", or "financial manager". We exclude farmers, civil servants, the military and clergymen from our sample. Over the period, jobs disappeared and others emerged as the LFS modified the job classification in 2003 to allow for changes in occupations. However, we are careful to maintain a consistent definition of jobs

\footnotetext{
${ }^{9}$ Basso, Peri, and Rahman (2017) also use occupational choices of highly and lowly qualified immigrants and natives to infer the evolution of the supply of manual, routine and analytical tasks in the US following the diffusion of computers. Adsera and Ferrer (2014) exploit the allocation of immigrant women across occupations in Canada to measure their skill assimilation.

${ }^{10}$ The quarterly sample is divided into 13 weeks. From a theoretical point of view, the sampling method consists in stratifying mainland France into 189 strata (21 French regions $\times 9$ types of urban unit), with a first-stage sampling of areas in each stratum (with different probabilities, the average sampling rate is 1/600). Areas contain about 20 dwellings; only primary residences are surveyed. Each area is surveyed over 6 consecutive quarters, dividing the sample into 6 sub-samples. Every quarter, 1/6 of the sample is surveyed for the first time, $1 / 6$ is surveyed for the second time, . . 1/6 is surveyed for the 6th (and last) time. When it was run as an annual survey, every year a third of the sample was renewed, meaning that each individual was interviewed only 3 times. The collection method has always been a face-to-face interview. However, since 2003 , telephone interviews have been employed for the $2^{\text {nd }}, 3^{\text {rd }}$ and $4^{\text {th }}$ surveys.
} 
throughout the 18 years of our sample, excluding any new occupations not included in the pre-2003 classification. This leaves us with 350 occupations consistently defined over the period.

Because the paper focuses on wage dynamics, we consider only individuals whose wage information is available. For the whole period 1993-2012 we have more than 714,000 observations. Immigrants represent around $11 \%$ of the yearly sample. They are on average slightly older, ${ }^{11}$ earn a slightly lower average real wage, and are less educated than native workers. ${ }^{12}$ The most important nativity groups are North-Africans, followed by SouthEuropeans and then other Africans. See Tables 2 and 3 in Appendix A.1 for further details on the sample.

\section{$2.2 \quad$ O*NET and EurOccupations databases}

The O*NET index is provided by the Department of Labor's Occupational Information Network. For the United States (U.S.), the O*NET database provides a detailed description of workers, occupations or jobs. We use information about occupational requirements to summarize the specific types of tasks that may be performed within occupations. The O*NET index is compiled according to the American Standard Occupational Classification (SOC). We expect the task content of occupations in France to be similar to the U.S. content, making the O*NET classification relevant to analyze the task content of French occupations. For our purpose, it is actually sufficient to assume that occupational rankings do not differ systematically between France and the U.S., and that an occupation ranking high in one task dimension in the U.S. also ranks high in the same dimension in France. ${ }^{13}$ We build a mapping table from the French classification PCS-ESE to SOC 2010 using the EurOccupations database, which covers 1,594 occupational titles within the ISCO-08 classification. ${ }^{14}$ Comparing the French PCS-ESE occupational classification with the EurOccupations classification, we find a perfect match for 412 occupations from the French classification with at least one from the EurOccupations database. Finally, we use a mapping table from the ISCO08 to the SOC- 2010 classification to link the PCS-ESE occupational classification with SOC-2010.

O*NET provides information on work activities, very close to the notion of task, for nearly 900 occupations, ranking 41 different tasks from 0 to 100 and indicating the degree (or point along a continuum) to which a particular descriptor is required or needed in the occupation. Because the $\mathrm{O}$ NET database does not provide information on workers, we are unable to monitor the evolution of task requirements within a given occupation. ${ }^{15}$ Note though that

\footnotetext{
${ }^{11}$ Note that we are not tracking immigrant cohorts, but the whole stock of immigrants with a positive wage (i.e. employed). Many immigrants start their labor market careers in the host country relatively late with respect to natives, which may explain why the whole stock of immigrants is found to be on average older, needing to work until later in life to become eligible for a retirement pension.

${ }^{12}$ France has a long history of immigration. Since 1974, immigration policy has been based mainly on family reunification with very little official labor-related immigration. Overall, and in comparison to other European countries, immigration policy has taken an increasingly restrictive course. Immigration remains strongly influenced to the present day by the legacy of colonialism and the economic and political situation in Southern Europe (Spain and Portugal). Few recent studies have analyzed the impact of immigrants on natives' labor market outcomes (see Edo and Toubal (2015), Ortega and Verdugo (2014) or Mitaritonna, Orefice, and Peri (2017)).

${ }^{13}$ In the extended version of their paper, Laffineur and Mouhoud (2015) use the German "Qualification and Career Survey" to build occupational task indices that they apply to the French professional classification of occupations. They take as starting point the estimations of Tidjens, Ruijter, and Ruikter (2011) who, working with 8 European countries (including Germany and France), find that occupational tasks performed in these countries are similar. Laffineur and Mouhoud (2015) show that differences between estimates using the German "Qualification and Career Survey" and those using O*NET cannot be attributed to differences in the task content of occupations between the U.S. and Germany (and thus France). They use estimates from the O*NET index since the O*NET provides more details on task intensity over a wider range of tasks.

${ }^{14}$ The EurOccupations project was aimed at building a publicly available database containing the most common occupations in a multi-country data collection. The database includes a source list of 1,594 distinct occupational titles within the ISCO-08 classification, country-specific translations and a search tree to navigate through the database. It also provides a mapping table between the EurOccupations classification and the ISCO-08 classification, as well as a French translation of these occupations. We are very grateful to Professor Kea Tijdens for allowing us to use this database.

${ }^{15}$ This is done in Atalay et al. (2018). Using the text from job ads, the authors construct a data set for occupational content from 1960 to 2000.
} 
our objective is to analyze the wage dynamics differential between natives and immigrants. Given that any change in the task content of an occupation will affect both immigrants and natives, this limitation should not therefore impede our analysis.

We apply the strategy of Autor, Katz, and Kearney (2008) and Autor and Dorn (2013) to the 41 tasks in O*NET, breaking them down into broad categories based on the Dictionary of Occupational Titles (DOT) provided by the US Department of Labor. The three broad categories are: ${ }^{16}$ non-routine manual tasks, routine (manual and cognitive) tasks, and non-routine (analytical and inter-personal) tasks. Once aggregated, we normalize these task indices. ${ }^{17}$ The last category corresponds to what Autor, Katz, and Kearney (2008) define as "abstract tasks", i.e. tasks performed by educated professionals and managers that require cognitive and interpersonal skills. ${ }^{18}$ Routine tasks refer to the clerical and routine cognitive and mechanical skills implemented in many middle-educated white collar and manufacturing production jobs. They correspond to easily programmable tasks, which follow repetitive, precise and well-defined procedures. Non-routine manual tasks are performed in many "low-skilled" service jobs such as health aides, security guards, orderlies, cleaners, and servers. These manual tasks demand interpersonal and environmental adaptability.

\section{Empirical Motivation}

Task-specific returns to skills have changed, following structural changes due to technological innovations and/or globalization, and may have contributed to the wage dynamics differential between immigrants and natives in two ways: (i) by inducing differing changes in the value of immigrants' and natives' skills in cases where initial task specialization differs between nativity groups (the price effect), (ii) by promoting differing task sorting in cases where comparative advantage differs between nativity groups (the quantity effect). In this section, we show that both the price effect and the quantity effect are actually good candidates to explain the differing wage dynamics of immigrants and natives, because immigrants and natives were differently distributed across occupations and thus tasks in 1994, and immigrants' occupational sorting from 1994 to 2012 differed from that of natives.

\section{INSERT FIGURE 2}

Figure 2 confirms that immigrants and natives differ in task specialization. The figure ranks individuals in ascending order into 5-percentile groups (20 groups) based on the wage distribution of natives in the initial period (1994). Individuals in the same group (whether natives or immigrants) have similar levels of productivity, though they may not have the same skill endowments and are not necessarily in the same occupation. For each nativity group, we report on the y-axis the average intensity of each task $k$ in the initial period, computed as follows: Task $k_{k 1994}=$ $\sum_{j}^{J} \operatorname{share}_{j 1994} \times \operatorname{Task}_{j k}$, where $\operatorname{share}_{j 1994}$ is equal to the share of occupation $j$ in total natives' or immigrants'

\footnotetext{
They document the importance of within-occupation task content shifts in accounting for the recent decrease in routine tasks.

${ }^{16}$ In Autor, Levy, and Murnane (2003) the authors consider five broad categories of tasks. Appendix A.2 summarizes the content of each of the five categories.

${ }^{17}$ For instance, using a two-digit classification of occupations; relative to blue collar workers, professionals (lawyers, doctors, etc.) perform tasks that are less non-routine manual ( 0.0789 vs 0.1589$)$, more non-routine abstract ( 0.9106 vs 0.1795$)$ and less routine intensive ( 0.1104 vs $0.1795)$.

${ }^{18}$ We do not distinguish between analytical and inter-personal tasks within abstract tasks. As pointed out by Yamaguchi (2018), it is difficult to separately identify their effects on wages using the DOT, because of their strong correlation. In addition, Yamaguchi (2010) stresses that inter-personal tasks may be not adequately measured by the DOT variables.
} 
employment, and $\operatorname{Tas}_{j k}$ is the O*NET index of task $k$ in occupation $j$, where $k$ is either (1) non-routine manual, (2) routine or (3) non-routine abstract. The differing average task intensities reflect a differing distribution across occupations (and thus across tasks) for immigrants and natives, although they may be located in the same vigintile of the wage distribution. The left-hand panel shows that at an identical position in the baseline-period wage distribution, immigrants are more specialized in manual tasks. The gap narrows sharply at the top of the distribution. The middle panel portrays a similar picture regarding routine tasks. However, the pattern of specialization is the opposite for non-routine abstract tasks (see right-hand panel), with natives more specialized than immigrants across the wage distribution. The gap between the two nativity groups remains fairly stable across the wage distribution and only narrows slightly at the top.

These differing patterns of task specialization in the two nativity groups provide the first potential explanation of the wage dynamics differential between immigrants and natives displayed in Figure 1. Specifically, immigrants' and natives' returns to skills may have evolved differently, despite identical changes in returns to tasks/skills for both groups over recent decades, because of differences in their initial task specialization. Beyond this price effect, such differences in task specialization also underlie the second explanation of the wage dynamics differential between immigrants and natives, i.e. the quantity effect. If different task specialization reflects different relative skill endowment, immigrants and natives may have reacted differently to changes in returns to tasks/skills and experienced different occupational sorting.

To assess the relevance of this second and complementary explanation, we report in Figure 3 changes between 1994-96 and 2010-2012 in the average task intensity of immigrants' and natives' occupational employment. As previously, the average task index is a weighted sum of a given task category index computed across the occupational employment distribution, with weights equal to the yearly share of each occupation in total employment of immigrants or natives. ${ }^{19}$ Between 1994-96 and 2010-12, both immigrants and natives moved away from non-routine manual and routine task-intensive occupations towards occupations intensive in non-routine abstract tasks. Consistent with results displayed in Figure 1, natives and immigrants reacted in the same direction following changes in returns to tasks. However, the dynamics were clearly more pronounced for immigrants. Overall, Figure 3 suggests that the occupational sorting induced by changes in returns to tasks contributed to a convergence in the type of tasks performed by immigrants and natives. ${ }^{20}$ The pace of immigrants' task sorting portrayed in Figure 3 may have contributed to their more favorable wage growth over the period.

\section{INSERT FIGURE 3}

These descriptive statistics suggest that both price and quantity effects could explain the difference in wage dynamics between immigrants and natives over the period 1994-2012. The next section derives an empirical definition of the components of the price effect and provides a definition of the quantity effect.

\footnotetext{
${ }^{19}$ The average intensity for each task $\mathrm{k}$ in period $\mathrm{t}$ is equal to $\operatorname{Task}_{k t}=\sum_{j}^{J} \operatorname{share}_{j t} \times \operatorname{Task}_{j k}$ where $\operatorname{share}_{j t}$ is equal to the share of occupation $j$ in period $t$ in total natives' or immigrants' employment and Task $k_{j k}$ is the intensity of task $k$ in occupation $j$, where $k$ is either (1) non-routine manual, (2) routine (both cognitive or manual) or (3) non-routine abstract.

${ }^{20}$ This convergent pattern of task specialization is in sharp contrast with that observed for the US by Basso, Peri, and Rahman (2017). They show that unlike natives, immigrants increasingly occupy manual jobs, and are less likely to be found performing abstract tasks.
} 


\section{Conceptual framework}

We consider a perfectly competitive environment with exogenous wages. The production side employs labor, measured in efficiency units, as a unique production input using a linear technology (i.e. marginal productivity of labor equals unity). At the competitive equilibrium, the price of the good produced will thus equal the wage per efficient unit of labor.

On the labor supply side, individuals differ in their skill endowment. To simplify, we focus on a particular skill $S$ (e.g. cognitive skills) heterogeneously distributed across individuals within the interval $[\underline{S}, \bar{S}]$. We normalize to unity the remaining skill bundle (e.g. manual skills) and we assume that it is homogeneously distributed across workers. ${ }^{21}$

\subsection{Occupation-specific production function}

The earning capacity of an individual with a relative skill endowment $S_{i}$ will depend on her occupation, since task composition and relative task intensity differ across occupations. As a consequence, each occupation requires more or less of $S$ to produce one efficient unit of labor. Since wages are defined by efficient units of labor, the earning capacity of an individual endowed with $S_{i}$ varies depending on the task composition of her occupation. More precisely, we consider 3 occupation categories: (i) those highly intensive in skill $S$ (denoted $H$ ); (ii) those requiring both skills and in which the tasks call for a moderate degree of skill $S$ (denoted $M$ ); and (iii) those weakly intensive in tasks requiring skill $S$ (denoted $L$ ).

For a given relative skill endowment $S_{i}$ the quantity of efficient units of labor, $s_{i j}$, provided by individual $i$ depends on her occupation according to:

$s_{i j}= \begin{cases}e^{\beta_{L}+\gamma_{L t} S_{i}} & \text { for } j=L \\ e^{\beta_{M}+\gamma_{M t} S_{i}} & \text { for } j=M \\ e^{\gamma_{H t} S_{i}} & \text { for } j=H\end{cases}$

Since we assume a linear technology, $s_{i j}$ is also the quantity of potential output of a worker in each occupation. Coefficients $\beta_{j}$ and $\gamma_{j t}$ are respectively the contributions of the general skill bundle and of skill $S$ to the production of efficient units of labor in each type of job. The ratio $\gamma_{j t} / \beta_{j}$ measures the relative intensity of tasks requiring skill type $S$ in occupation $j$. Parameters $\beta_{j}$ and $\gamma_{j t}$ are proportional to the earning capacity of a worker in a particular occupation. Moreover, we assume that $\gamma_{H t}>\gamma_{M t}>\gamma_{L t}$ and $\beta_{L}>\beta_{M}$. The earning capacity of skills $S$ will then be highest in $H$ occupations and lowest in $L$ occupations, while for the complementary skill bundle we assume the opposite: highest earning capacity in $L$ jobs. Similarly to Gibbons et al. (2005), these differential weights generate a sorting of workers based on their comparative advantage.

\subsection{Workers' earnings}

\footnotetext{
${ }^{21}$ This simplification is consistent with our econometric approach, where we look at the partial effect of a task dimension, keeping constant other measures of task intensity. We therefore focus on relative task or skill intensity.
} 
Wages per efficient unit of labor differ from one occupation to another and returns to an identical skill endowment differ depending on the task composition of an occupation. Therefore, the wage of a worker with a quantity of efficient labor equal to $s_{i j}$ will differ depending on her occupation. Workers are paid the value of their marginal product. The wage received by a worker in each occupation is equal to $W_{i j t}=s_{i j t} \times p_{j t}$, for $j=L, M, H$, where $p_{j t}$ stands for the time-varying price index of the specific goods or services provided by the occupation. With the log-specification:

$$
\begin{aligned}
& \ln \left(W_{i L t}\right) \equiv \omega_{i L t}=\ln \left(p_{L t}\right)+\beta_{L}+\gamma_{L t} S_{i} \\
& \ln \left(W_{i M t}\right) \equiv \omega_{i M t}=\ln \left(p_{M t}\right)+\beta_{M}+\gamma_{M t} S_{i} \\
& \ln \left(W_{i H t}\right) \equiv \omega_{i H t}=\ln \left(p_{H t}\right)+\gamma_{H t} S_{i}
\end{aligned}
$$

where $p_{j t}$ and $\gamma_{j t}$ are allowed to change over time. In this setting, conditional on distribution of skills, the dynamics of wages (within and across occupations) and workers' occupational sorting will depend on occupation-specific price changes $p_{j}^{\prime} s$, and changes in occupation-specific skill returns $\gamma_{j}^{\prime} s$.

\subsection{Worker sorting across occupations}

Income maximization implies that each worker chooses the job offering the highest wage given her relative skill endowment:

$W_{i j t}^{*}=\arg \max _{j=L, M, H}\left\{W_{i L t}, W_{i M t}, W_{i H t}\right\}$

We illustrate in Figure 4 one pattern of worker sorting across the three occupations. Those with the lowest $S$ endowment choose $L$ occupations, where the earning capacity of skill $S$ is lowest and the earning capacity of the complementary bundle of skills is highest. Workers with a medium $S$ endowment choose $M$ occupations, and those with the highest $S$ endowment choose $H$ occupations.

Within a given type of occupation, workers are heterogeneous in terms of skill endowment and therefore earn different wages. Since workers' earning capacity is a monotonic transformation of their skill endowment, a worker's position in the wage distribution within an occupation corresponds to her position in the relative skill endowment distribution of the occupation. ${ }^{22}$ We will rely on this rank-order preservation assumption in our econometric approach.

\section{INSERT FIGURE 4}

\subsection{The dynamics of occupational wages}

\subsubsection{Parameter identification: the price effect}

Using this basic conceptual framework, we characterize the factors driving the dynamics of wage disparities. Individual (log) wages in a particular occupation $j=L, M, H$ are given by $\omega_{i j t}=\ln \left(W_{i j t}\right)=\ln \left(p_{j t}\right)+\beta_{j}+$

\footnotetext{
${ }^{22}$ While working with skills rather than qualifications allows us to partially control for traditional discrimination against immigrants (nonrecognition of foreign qualifications or foreign professional experience), the wage received by an immigrant may still under-represent her skill endowment due to discrimination issues. In this work, we are unable to control for this type of discrimination.
} 
$\gamma_{j t} S_{i}$. Under the assumption of constant skill distribution within occupations, that is, under the assumption that there is no sorting of workers across occupations following changes in returns to skills, we can estimate the proportion of the wage dynamics that corresponds to the price effect. In our simplified Roy-type wage setting, we distinguish between two determinants of wage dynamics (when the skill distribution within occupations is constant): (i) returns to skills $\left(\gamma_{j t}\right)$, and (ii) a demand/supply effect inducing a change in price $p_{j t}$. This last effect is driven by potential changes in demand and/or supply for the occupation-specific good/service.

The demand/supply effect induces wages to evolve across occupations, shifting the whole wage distribution up or down. Changes in returns to skills $\left(\gamma_{j t}\right)$ induce wages to evolve both within and across occupations. Occupations characterized by decreasing (increasing) returns to skills will be characterized by a reduced (increased) withinoccupation wage inequality and, at the same time, will move downward (upward) on the occupational wage ladder.

Because we do not have individual longitudinal data but simply a pool of cross sections, we assume that individuals' position in the wage distribution within a particular occupation corresponds to their position on the relative skill endowment distribution of the occupation, consistent with our theoretical framework. Moreover, when interpreting our results, we will assume that, conditional on a set of observable characteristics, the skill distribution within an occupation remains constant over time. ${ }^{23}$ We will use counterfactual weights to ensure that the age-education composition (and the length of residence composition when working with immigrants) within every occupation is identical across periods. Under the hypothesis that the relative skill distribution within an occupation is constant, we can denote $F_{j}$ the time-invariant distribution of efficient units of labor, $s_{i j}$, in an occupation $j=L, M, H$. With a suitable normalization, the $q^{\text {th }}$ quintile of the distribution of wages can be written as:

$\omega_{j t}^{q}=\bar{\omega}_{j t}+\gamma_{j t} F_{j}^{-1}(q)$

where $\bar{\omega}_{j t}=\ln \left(p_{j t}\right)+\beta_{j}+\gamma_{j t} \bar{S}_{i j}$ is equal to the average (log) wage. The wage at quintile $q$ equals the average wage in the occupation plus the marginal skill return $\gamma_{j t}$ multiplied by the skill level at the corresponding quintile. Taking differences over time leads to:

$\Delta \omega_{j t}^{q}=\Delta \bar{\omega}_{j t}+F_{j}^{-1}(q) \Delta \gamma_{j t}$

Solving for $F_{j}^{-1}(q)$ in (3) at the base period gives $F_{j}^{-1}(q)=\left(\omega_{j 0}^{q}-\bar{\omega}_{j 0}\right) / \gamma_{j 0}$. Replacing in the previous equation yields:

$\Delta \omega_{j t}^{q}=\Delta \bar{\omega}_{j t}+\left[\left(\omega_{j 0}^{q}-\bar{\omega}_{j 0}\right) / \gamma_{j 0}\right] \Delta \gamma_{j t}=\Delta \bar{\omega}_{j t}+\left(\frac{\Delta \gamma_{j t}}{\gamma_{j 0}}\right)\left(\omega_{j 0}^{q}-\bar{\omega}_{j 0}\right)=a_{j}+b_{j}\left(\omega_{j 0}^{q}-\bar{\omega}_{j 0}\right)$

where $\left(\omega_{j 0}^{q}-\bar{\omega}_{j 0}\right)$ is simply a normalization (quintiles are written as deviation from occupation average wage in the base period).

Under the hypothesis of time-invariant skill distribution within occupations, we can exploit decile-specific wage

${ }^{23}$ A similar assumption is for instance exploited by Acemoglu and Autor (2011) to infer the impact of changes in task prices on wage inequality. 
changes within each occupation to identify two synthetic measures of the dynamics of wage distribution (i.e. price effect) across and within occupations. The first measure summarizes changes in the average wage of the occupations, i.e. between-occupation wage changes, and is represented by the term $a_{j}=\Delta \bar{\omega}_{j \mathrm{t}}=\Delta \ln \left(p_{j t}\right)+$ $\bar{S}_{i j} \Delta \gamma_{j t}$ in each occupation $j$. This dimension of wage growth will vary across occupations due to the differing evolution of the market price of occupation-specific goods and services and/or due to changes in the returns to skills used to perform the set of occupation-specific tasks. The second measure summarizes changes in wage disparities within the occupation, i.e. within-occupation wage changes, and is represented by the term $b_{j}=$ $\Delta \gamma_{j t} / \gamma_{j 0}$. It measures how changes in returns to skills have impacted wage differences between workers employed in the same occupation but having different levels of skills, as measured by their position in the occupation-specific wage distribution.

Under the assumption that the skill distribution within occupations does not change over time, there is a clear positive correlation between average wage changes across occupations (i.e. between-occupation wage changes) and wage changes within occupations, i.e. $\operatorname{Cov}\left(a_{j}, b_{j}\right)>0$, since both dimensions depend on returns to skills component $\gamma_{j t}$.

\subsubsection{Identification issues: the quantity effect}

Our identification strategy for the price effect strongly relies on the hypothesis of time-invariant skill distribution within occupations, ${ }^{24}$ since otherwise we are not able to identify the between- and within-occupation components. This assumption is clearly inconsistent with the sorting behavior of workers across occupations, based on their comparative advantages. Job selection will be driven by both components of the price effect: between- and withinoccupation wage changes. The quantity effect refers to the part of the wage dynamics driven by the differential in immigrants' and natives' sorting across occupations following similar changes in price and skill returns. This section explains the quantity effect in more detail.

At the equilibrium, the mapping of abilities into efficient units of labor and the optimal decision rule (2) define two thresholds determining occupational sorting:

(i) $S_{l t}=\frac{\ln \left(p_{L t} / p_{M t}\right)+\beta_{L}-\beta_{M}}{\gamma_{M t}-\gamma_{L t}}$, which corresponds to the skill level such that $W_{i L t}=W_{i M t}$, and

(ii) $S_{h t}=\frac{\ln \left(p_{M t} / p_{H t}\right)+\beta_{M}}{\gamma_{M t}-\gamma_{L t}}$, which corresponds to the skill level such that $W_{i H t}=W_{i M t}$.

As shown by Figure 4, all individuals $i$ with $S_{i}<S_{l t}$ choose the $L$ occupation, all $i$ with $S_{l t}<S_{i}<S_{h t}$ choose the $M$ occupation and all $i$ with $S_{i}>S_{h t}$ choose the $H$ occupation. Any exogenous variation in price $p_{j t}$, or any technological change modifying the relative contribution of skills to efficient units of labor, will trigger a change in these threshold values and thus workers' reallocation across occupations, since the unitary price of their skills will be modified. For instance, a decrease in $p_{M t}$ (see left-hand panel of Figure 9 in Appendix C.2) increases $S_{l t}$

\footnotetext{
${ }^{24}$ This hypothesis will be translated into a counterfactual reweighting procedure in our econometric approach.
} 
and decreases $S_{h t}$. Workers move away from $M$ occupations towards $L$ and $H$ occupations. In $M$ occupations, the least skilled workers (those with a weak comparative advantage in $M$ relative to $L$ occupations) move towards $L$ occupations, while the most skilled workers (those with a weak comparative advantage in $M$ relative to $H$ occupations) move towards $H$ occupations. As a result, the labor share of occupations at the upper and lower ends of the skill distribution expands while that in the middle contracts. Wage distribution will narrow in $M$ occupations and will widen in $H$ and $L$, even though returns to skills and/or skill prices have not changed in these two occupations. Similarly, if returns to cognitive skills $\left(\gamma_{H}\right)$ increase in $H$ occupations (see right-hand panel of Figure 9 in Appendix C.2), there will be a decrease in $S_{h t}$, with the most skilled workers in $M$ moving towards $H$ occupations and thus increased wage dispersion within $H$ occupations. Again, wage distribution will narrow in $M$ occupations.

Endogenous selective sorting of workers across occupations suggests that the skill distribution within occupations will not be fixed over time as we assumed when identifying $\Delta \gamma_{j t}$ and $\Delta p_{j t}$. Moreover, the direction of the bias is unclear. Depending on the exact distribution of $S$ skills, stayers in $M$ occupations can be on average less or more skilled than movers. For instance, if $M$ occupations are intensive in routine tasks, and $H$ and $L$ occupations are respectively intensive in non-routine abstract and non-routine manual tasks, following a decrease in the price of goods and services intensive in routine tasks we will overestimate the importance of wage changes in $L$ occupations (since newcomers are relatively more skilled), and underestimate wage changes in $H$ occupations (since newcomers are relatively less skilled). Therefore simply considering the average wage and wage dispersion changes will not explain the wage dynamics differential between natives and immigrants.

To control for worker sorting, we would need to follow workers over time as in the recent contribution of Cortes (2016), to distinguish stayers from movers. Here, we only have successive cross-sectional data. Therefore, and following Acemoglu and Autor (2011), when estimating the price effect we will be able to control for selection only on observable characteristics, that is we will be measuring wage changes that occur among individuals who are similar across a fixed set of observable characteristics. We will be using counterfactual weights to compare wage changes along the wage distribution of every occupation for workers having the same observable skill distribution within occupations, which we take to be equal to that of the baseline period (i.e. before the change in task returns). Moreover, in order to focus on occupation-specific skills and not on general skills, whose returns may have changed, we will rely on residual wage changes as in Autor, Katz, and Kearney (2008). This is important, for instance, if some occupations attract more educated workers and the returns to education rise over time, otherwise we would be measuring the mechanical effect of rising returns to education instead of occupation-specific skill returns. ${ }^{25}$

To assess the quantity effect, we relax the assumption of fixed distribution of workers across tasks (and thus constant skill distribution within occupations). We estimate a conditional logit model to assess whether immigrants

\footnotetext{
${ }^{25}$ Using Canadian data, Boudarbat and Lemieux (2014) actually find that both changes in the mean wage gap between natives and immigrants and changes in the gap at different quantiles of the wage distribution are explained by standard factors such as experience, education, and country of origin of immigrants
} 
and natives, facing similar changes in good/service prices and skill/task returns, show different sorting patterns over time across occupations and tasks. This approach allows us to draw conclusions on the potential impact on wage dynamics of workers' selective mobility across tasks.

\section{Results}

\subsection{The price effect}

In this section we first estimate the price effect and then analyze how far this effect can be attributed to the specific tasks. To estimate the price effect, we first compute the residual wage of every male participant in the $\mathrm{LFS}^{26}$ by estimating equation (13) in Appendix C.3. Because the LFS provides information on individuals' occupations, once we have computed every participant's residual wage, we also have the wage distribution within every occupation. We then decompose this wage distribution into 9 deciles and exploit within- and between-occupation time variation in wage deciles to characterize wage changes. The two occupation-specific components defined in the previous section - i.e. the within- and between-occupation components - are estimated under the assumption that the skill distribution within occupations is constant. These components are estimated separately for each nativity group.

In a second step, we compare immigrants' and natives' wage growth within and across occupations conditional on fixed task specialization. Throughout the procedure, we apply counterfactual weights $\grave{a} l a$ Lemieux (2002) to filter out any effects from changes in population composition in terms of age, education and length of residence (see Appendix B for a detailed explanation).

\subsubsection{Estimating the price effect: between- and within-occupation components}

We focus on males' residual wage changes between the periods 1994-96 and 2010-12, $t=0$ and $t=1$ respectively. ${ }^{27}$ Focusing on longer-term differences helps to limit the influence of short-term variations and thus to identify long-term effects on wage dynamics of changes in prices and skill returns. In addition, using longer-term differences instead of year-to-year changes avoids serial correlation issues that could lead to understating the estimated standard errors (see Bertrand, Duflo, and Mullainathan (2004)). Moreover, the number of observations per occupation is increased by including three years of data in each of the two longer periods. This is necessary due to the detailed definition of occupations used (four digits). ${ }^{28}$ Residual wages $\tilde{w}_{\text {int }}$ for each period $(t=0,1)$ are obtained from the estimation of a wage equation where we partial-out the effects of observable characteristics (age, education, length of residence, country of origin) - see Equation (13) in Appendix C.3. Working with residual wages allows us to control for wage disparities across workers that are not specifically related to their occupation. These residual wages are then grouped by deciles within each occupation to form an occupation-specific residual wage distribution ( 9 deciles per occupation) at each period. We focus on wage decile changes within occupations

\footnotetext{
${ }^{26}$ Excluding females simplifies the analysis by avoiding consideration of gender specificities in labor supply choices. See Edo and Toubal (2017) for an analysis of the impact of immigration on the French gender gap.

${ }^{27}$ Data prior to 1993 are difficult to use because of a substantial change in the French Industry Classification (NAF) that prevents us from having an unequivocal correspondence between industry codes before and after 1993. This is a problem in our case because some jobs are defined for a specific industry. The Labor Force Survey 2012 contained the most recent available data at the time of writing this paper. Note also that each period corresponds to the final part of a crisis: the nineties crisis for period 1994-1996 and the recent economic crisis for period 2010-2012.

${ }^{28}$ Otherwise, when working with immigrants, we would not have enough observations per occupation and per period.
} 
(e.g. between the 4th wage decile of actuaries in period 1 and the 4th wage decile of actuaries in period 0 ).

To characterize these wage changes, we estimate separately for each nativity group the two occupation-specific components defined in equation (5): the between-occupation component (intercept $a_{j}$ ) and the within-occupation component (slope $b_{j}$ ). Specifically, we estimate a linear relationship between the residual wage change at each occupation-specific decile $q, \Delta \tilde{\omega}_{j}^{q}$, and the corresponding level of wage decile $q$ at the base period $(t=0), \tilde{\omega}_{j 0}^{q}$ :

$\Delta \tilde{\omega}_{j}^{q}=a_{j}+b_{j} \tilde{\omega}_{j 0}^{q}+\lambda_{j}+v_{j}^{q}$

where $v_{j}^{q}$ is an idiosyncratic error term. We also consider a decile-specific error component, $\lambda_{j}$, representing a generic change in returns to skills common to all occupations but specific to one wage decile. ${ }^{29}$ Computing wage decile changes (e.g. between the 4th wage decile of actuaries in period 1 and the 4th wage decile of actuaries in period 0) requires a sufficient number of observations in each occupation..$^{30}$ Overall, we are left with 229 occupations for natives and 125 occupations for immigrants. Both $b_{j}$ and $a_{j}$ measure the shift in the occupational wage distribution and both are affected by changes in occupation-specific returns to skills, $\Delta \gamma_{j t}$. In addition, intercept $a_{j}$ also depends on changes in the price of occupation-specific goods and services, which are not directly related to changes in returns to skills.

We estimate separately the price effects $\left(b_{j}\right.$ and $\left.a_{j}\right)$ for natives (over 229 occupations) and immigrants (over 125 occupations) and analyze their impact on the wage dynamics differential across nativity groups, under constant and similar population composition. Results are summarized in Figure 5 (as well as Figure 13 in Appendix C.4). The $\mathrm{X}$-axis represents the occupational wage or skill ladder (we rank occupations according to the natives' median wage in period 0), while the Y-axis represents the between-occupation component, $a_{j}$ (left-hand panel) and the withinoccupation component, $b_{j}$ (right-hand panel). We restrict in this Figure to a subset of 124 occupations where we can estimate components $a_{j}$ and $b_{j}$ for both immigrants and natives. It can be seen that for both immigrants and natives, average occupational wage growth (the between component) is higher in better-paid (more skilled) occupations, and even higher for immigrants. As shown in the right-hand panel of Figure 5 (within component), this pattern is little influenced by differences in returns to skills between immigrants and natives. Thus, immigrants' better average wage performance seems more due to their skill endowments than to the difference in their returns to skills. ${ }^{31}$

\section{INSERT FIGURE 5}

Having estimated both components of the price effect, we examine in the next section how far this effect is attributable to skill endowment differences between immigrants and natives. When returns to identical tasks (which proxy skills) differently impact the wage dynamics of immigrants and natives employed in the same occupations,

\footnotetext{
${ }^{29}$ This would capture, for instance, the effect of some labor market institutions (minimum wage, occupation-level wage negotiations) which will more greatly affect the bottom wage deciles of all occupations.

${ }^{30}$ In fact, each wage decile needs to be separately observed in each period. This requires at least 10 observations per period for each occupation and nativity group.

${ }^{31}$ To see this, note that the wage growth premium of immigrants relative to natives within an occupation is equal to: $\Delta \omega_{j t}^{I M}-\Delta \omega_{j t}^{N A}=\Delta \gamma_{j t} \times$ $\left(\overline{S_{J}^{I M}}-\overline{S_{J}^{N A}}\right)$, where $\left(\overline{S_{J}^{I M}}-\overline{S_{J}^{N A}}\right)$ is the difference in skill endowments in occupation $j$ between immigrants and natives.
} 
immigrants and natives can be considered to differ in their relative skill endowments.

\subsubsection{Task impact on price effect}

As suggested by our Roy conceptual framework, workers in the same occupation do not necessarily have the same skill endowments, even if they have the same observable characteristics (i.e. age, education and length of residence). Even if returns to skills/tasks are identical for all workers employed in a given occupation and performing the same tasks, two workers with different skill endowments can experience different wage changes. In this case, returns to skills/tasks could contribute differently to wage changes between and within occupations.

To assess native-immigrant differences in skill endowments, we use as dependent variables the coefficients $a_{j}$ and $b_{j}$ estimated in the previous section for each occupation. We collect as many coefficient estimates $\left(\hat{a}_{j}, \hat{b}_{j}\right)$ as there are occupations employing both immigrants and natives, ${ }^{32}$ leaving us with 124 occupations common to both groups (i.e. 248 observations). If within an occupation returns to identical tasks $k$ contribute differently to the occupational wage dynamics $\left(a_{j}\right.$ and $\left.b_{j}\right)$ of natives and immigrants, it is reasonable to assume that the skill endowment required to perform task $k$ differs between natives and immigrants. ${ }^{33}$ From the pooled sample of coefficients estimated for immigrants and natives, we estimate the following reduced-form relationships:

$\hat{a}_{j i}=\alpha_{0}+\alpha_{I}$ Immigrant $_{i}+\sum_{k=1}^{3} \alpha_{k} T C_{j k}+\sum_{k=1}^{3} \alpha_{k}^{I}$ Immigrant $_{i} \times T C_{j k}+\mu_{i j}$,

$\hat{b}_{j i}=\delta_{0}+\delta_{I}$ Immigrant $_{i}+\sum_{k=1}^{3} \delta_{k} T C_{j k}+\sum_{k=1}^{3} \delta_{k}^{I}$ Immigrant $_{i} \times T C_{j k}+v_{i j}$,

where Immigrant $_{i}$ is a dummy variable taking the value 1 if the coefficient was estimated on the sample of immigrants, 0 otherwise. $T C_{j k}$ is the task intensity index for each occupation $j$ and task category $k=(1)$ non-routine abstract, (2) routine, and (3) non-routine manual. Note that task intensity indices are unit-based normalized across occupations and estimations are weighted according to the size of the nativity group in the occupation. Because we are using initial period weights, we ensure that differences in wage dynamics between immigrants and natives are not driven by changes in the occupational (or task composition) distribution over time. Coefficients $\alpha_{I}$ and $\delta_{I}$ capture systematic differences in wage dynamics between immigrants and natives. Coefficient $\alpha_{I}$ allows us in particular to test for an immigrant wage growth premium, as suggested in Figure 5. Coefficients $\alpha_{k}$ and $\delta_{k}$ measure the impact from returns to each task $k$ on natives' wages across $\left(\hat{a}_{j i}\right)$ and within $\left(\hat{b}_{j i}\right)$ occupations, ${ }^{34}$ while coefficients $\alpha_{k}^{I}$ and $\delta_{k}^{I}$ capture the difference in these components' impact on immigrants. By estimating the latter coefficients, we can specifically test whether returns to tasks differently impacted the wage dynamics of natives and immigrants performing similar tasks, and thus identify immigrant-native differences in skill endowment. ${ }^{35}$

\footnotetext{
32 The common support includes 124 occupations, giving us 124 between-occupation coefficients for natives and 124 between-occupation coefficients for immigrants; the same applies to within-occupation coefficients.

33 Again, significantly different impacts of returns to tasks on between- or/and within-occupation wage changes could suggest either discrimination (i.e. identical skill endowments are differently rewarded) or a skill endowment differential between natives and immigrants (i.e. returns to skills are identical but the skill endowment differs between the two nativity groups). However, unravelling these two explanations is beyond the scope of this paper.

34 Parameter estimates of the above equations when working separately with the native and the immigrant sample are available from the authors upon request.

35 The fact that the dependent variable is estimated introduces measurement error and loss of efficiency, but unlike measurement error in independent variables, does not hinder regression analysis (see Maddala (2001), p. 64, for a standard reference). These measurement errors
} 
Our estimates also take into account two other potential drivers of the wage dynamics differential between immigrants and natives. First, labor demand may evolve due to changes in the national output mix, and this may affect occupations differently depending on their initial distribution across sectors. Given that immigrants and natives, within the same occupation, may be employed in different sectors, they will be differently impacted by these changes regardless of their relative skill endowments. To mitigate this effect, we include in our regressions an occupation-specific labor demand shift index à la Bartik (1991). This index is constructed from the distribution of occupations across sectors in 1994-1996 and takes into account changes in industrial composition between periods 1994-1996 and 2010-2012. ${ }^{36}$

\section{INSERT TABLE 1}

Second, our estimates take into account workers' sorting on observable characteristics so as to eliminate effects from a composition differential between immigrants and natives. We consider three different weighting schemes, as described in Appendix B: baseline, weighting 1 and weighting 2 schemes. The baseline scenario uses the LFS original population sample weights; populations are therefore representative of their specific nativity group in each period. Weighting scheme 1 ensures a constant population (age*education) composition within occupations for each nativity group separately. We therefore focus on the sub-population most likely to work in an occupation before the shift in skill returns. Weighting scheme 2 ensures that within occupations the population composition (in terms of age and education) is not time-varying and is the same for both nativity groups, thereby controlling for different composition effects across nativity groups and over time. Estimations using weighting scheme 2 are thus the most consistent with the assumption of constant population composition within occupations in our Roy-type framework. Depending on the scenario, sample size varies from 248 to 144 observations (i.e. from 124 to 72 common occupations per nativity group, respectively).

Estimates from equations (7) and (8) are reported in Table 1. The coefficient of the Immigrant dummy variable is consistent with the finding reported in Figure 5: across occupations, immigrants' relative wage growth (i.e. between-occupation effect) outperformed that of natives by $24 \%$ over the 20 years (see column 3 ). This is quite substantial given that we control for observable characteristics such as age, education and length of residence. Wage returns to non-routine skills (abstract and manual) contributed to average wage growth (i.e. between-occupation effect), while returns to routine skills had a rather negative influence. Including immigrants' specific returns to tasks in the regression does not significantly change the estimated wage growth premium of immigrants over the period (see Tables 5 and 6 in Appendix D for coefficient estimates without these controls). Thus, the immigrants' wage growth premium does not seem to be driven by immigrant-specific returns. Estimates in Table 1 reveal that

will introduce heteroskedasticity if they are not constant across observations. We correct for this using White (1980)'s standard error adjustment. While some authors have suggested using weighted least-square adjustment, through a series of Monte Carlo experiments, Lewis and Linzer (2005) show that the efficiency gains are generally very limited.

36 We define as follows the labor demand shift indicator for occupation $j$ and origin $i$ : DemandShift ${ }_{j i}=\sum_{s}\left[\frac{N_{s j i 0}}{N_{j i 0}} \Delta N_{s i}\right]$, where $N_{s j i 0}$ stands for the number of employees of origin $i$ in sector $s$, occupation $j$ in period 0 (base period). $N_{j i 0}$ represents the total number of employees of origin $i$ in occupation $j$ in period $0 . \Delta N_{s i}$ is the variation in the number of employees of origin $i$ in sector $s$. To obtain the labor demand shift associated with an occupation, we must sum shifts over all sectors $s$ composing occupation $j$. 
there is virtually no immigrant-specific task return that significantly differs from that of natives in its impact on between-occupation wage changes. This suggests that immigrants' wage growth performance is not related to their specific skill endowment for certain tasks.

However, the picture changes when we look at the evolution of returns to skills (i.e. within-occupation wage changes). Once composition effects have been controlled for (column 6), in occupations requiring non-routine manual skills we find immigrants' wages compressing, while natives' wage dispersion increases. This pattern is likely due to changes in the skill endowments of immigrants and natives in non-routine manual occupations. ${ }^{37} \mathrm{As}$ the next section shows, immigrants' specialization in non-routine manual tasks decreased sharply over the period (see also Figure 3). If this occurs within age and education groups, it may lead to wage compression among immigrants in these occupations. ${ }^{38}$

Immigrants may have responded differently from natives to incentives driven by price effects. In the next section, we relax the assumption of constant relative skill distribution within occupations over time. First, we assess the dynamics of occupational sorting for immigrants and natives depending on the between- and within-occupation components of wage changes. Second, we relate immigrants' and natives' occupational sorting to the task content of occupations.

\subsection{Quantity effect}

How have immigrants' and natives' occupational choices been impacted by changes in average wages (betweenoccupation wage change) and returns to skills (within-occupation wage change)? Both are likely to alter individual decisions on skill acquisition and occupational choices. Differing occupational choices between immigrants and natives facing identical price changes would suggest differing changes in their respective skill endowments. Patterns of occupational sorting may explain immigrants' relatively higher wage growth across the occupational wage distribution.

To capture the occupational sorting pattern differential between immigrants and natives, we first estimate the quantity effect by relating occupational choices to the two components of wage changes previously estimated for each occupation (i.e. between- and within-wage components). This allows us to test whether immigrants and natives sort differently across occupations in response to identical wage changes. Second, we characterize differences in the occupational sorting of immigrants and natives by relating their occupational choices to the task content of occupations. We do so by estimating a simple occupational choice model.

\footnotetext{
${ }^{37}$ Note that whether initial skill endowment is the same or not for natives and immigrants, the negative and significant coefficient associated with the variable "Img. Non-routine manual" (compared to the positive and significant coefficient associated with "Non-routine manual") can only arise if there is a shift in the relative skill endowment of immigrants versus natives.

${ }^{38}$ To test the robustness of these results, we propose in Appendix D an alternative strategy consisting in regressing the immigrant-native gaps in estimated between- and within-occupation components over the task indices:

$$
\begin{aligned}
& \hat{a}_{I}-\hat{a}_{N}=\tau_{0}+\tau_{1} \text { DemandShift }_{j}+\sum_{k=1}^{3} \tau_{k} T C_{j k}^{n o r m}+\mu_{j} \\
& \hat{b}_{I}-b_{N}=\varphi_{0}+\varphi_{1} \text { DemandShift }_{j}+\sum_{k=1}^{3} \varphi_{k} T C_{j k}^{\text {norm }}+v_{j}
\end{aligned}
$$
}

where $T C_{j k}^{n o r m}$ again stands for the normalized task content measure within each occupation $k=(1)$ non-routine abstract, (2) routine and (3) non-routine manual. Results in Table 7 in Appendix D are consistent with estimations in Table 1. 
Our occupational choice model, based on the conceptual framework presented in Section 4, is easily framed within a probabilistic or random utility choice model. We assume that when choosing their occupation, individuals consider not only potential income related to their relative skill endowment but also some stochastic and idiosyncratic characteristics of occupations, whose distribution is assumed to be independent of workers' skill endowments. From a variety of occupations, they choose their best option, taking into account both the income potential and these specific characteristics. The indirect utility that a worker $i$ derives from choosing an occupation $j$ depends on her potential earnings in the occupation, which we assume is a linear function of individual characteristics $X_{i}$, occupation-specific characteristics $Z_{j}$ (occupation-specific returns to skills), and an idiosyncratic stochastic component:

$U_{i j}^{*}=\rho_{i} X_{i}+\kappa_{i j} Z_{j}+\varepsilon_{i j}$

An individual will choose among $J$ occupations the one that provides the highest utility. We assume that the effects of occupation-specific characteristics on individual utility $\left(\kappa_{i j}\right)$ vary across individuals, for instance according to their specific skill endowments. ${ }^{39}$ An individual will choose occupation $j$ if $U_{i j}^{*}>U_{i k}^{*} \forall k \neq j$.

We define $U_{i j}=1$ if individual $i$ chooses occupation $j$ and $U_{i j}=0$ otherwise. Assuming that the disturbance terms are identically and independently distributed (iid) and follow a Type-I extreme value distribution, ${ }^{40}$ we can estimate this random utility model using McFadden (1974)'s conditional logit:

$\operatorname{Pr}\left(U_{i j}=1\right)=\frac{\exp \left(\rho_{i} X_{i}+\kappa_{i j} Z_{j}\right)}{\sum_{j=1}^{J} \exp \left(\rho_{i} X_{i}+\kappa_{i j} Z_{j}\right)}$

Terms that do not vary across alternatives and are specific to the individual (i.e. $X_{i}$ ) are irrelevant and fall outside the probability. Therefore, we cannot estimate the effect of individual characteristics on occupational choice $(\rho)$ since they are invariant to choice. However, we can estimate the effect on occupational choice of occupationspecific characteristics $(\kappa)$, such as their task content, or their wage growth, and also the interactions of these with individual-specific characteristics. To track the effect of changes in occupation-specific characteristics, we allow the effects to vary over time by interacting each characteristic with a dummy variable Year, equal to one in 201012. Therefore, we interpret coefficients from a dynamic point of view, with respect to the base period (1994-1996). Coefficients associated with these interaction terms capture change relative to the base period in the probability of choosing an occupation on the basis of its characteristics.

\subsubsection{Estimating the quantity effect: occupational choice}

Let us begin by estimating the pure quantity effect, which relates occupational choice to the between- and withinoccupation components of wage changes (i.e. $a_{j}$ and $b_{j}$ ). To do so, we include the two wage growth components in the conditional logit as explanatory variables, interacting them with the period dummy Year. Therefore our

\footnotetext{
${ }^{39}$ In this setting, Xi can be considered as the vector of individual skill endowments and $\mathrm{Zj}$ as a vector denoting the sensitivity of the occupation to each skill component of $\kappa_{\mathrm{ij}}$.

${ }^{40}$ Under the independence of irrelevant alternatives (IAA) assumption, choices are independent of irrelevant alternatives and therefore the omission of a choice does not significantly alter estimates.
} 
analysis focuses on the coefficients associated with the interaction terms Year $\times a_{j}$ and $Y e a r \times b_{j}$. Using the estimated conditional logit model, we graphically represent the change in the predicted probability of choosing a given occupation in period 2 relative to period 1 , at different values of $a_{j}$ and $b_{j}$ components. Results are given in Figure 6. The $\mathrm{X}$-axis of the left-hand and right-hand panels displays, respectively, the 10th, 25th, 50th, 75th and 90th percentiles of the distribution of the between- and within-occupation components of wage changes previously obtained from estimating equation (6) over the sample of natives when controlling for composition effects (i.e. Weight 2). The Y-axis represents the variation in the probability of choosing an occupation located at the corresponding percentile of the specific component of wage changes with respect to the base period 1994-1996 (i.e. relative marginal effect estimated at a given percentile of the wage component). An upward profile along the distribution of the between- (within-) occupation component indicates that occupations showing a relatively higher average wage (wage dispersion) increase are more likely to be chosen over time. In contrast, a downward profile indicates that these occupations are less likely to be chosen over time. The interpretation of results in Figure 6 should therefore focus on the slope of the curve and not the associated absolute values of the marginal effects, which are actually defined in relative terms.

The solid curves represent the results for the observed population sample, while the dashed curves represent the results with a reweighted sample keeping population composition constant over time and across nativity groups (i.e. same age-education composition in both periods for immigrants and natives and same length of residence for immigrants in both periods). The latter results provide a more consistent estimate of the contribution of the quantity effect to the wage dynamics differential between immigrants and natives.

The left-hand panel of Figure 6 reveals that sorting is positive: occupations with greater between-occupation wage changes (i.e. average wage growth) are increasingly likely to be chosen by both immigrants and natives. Natives' sorting in such occupations is entirely driven by their skill upgrading in terms of age and education: when composition effects are removed, we actually find that the probability of natives choosing occupations with a higher between-occupation wage change decreased between 1994-1996 and 2010-2012. In contrast, at similar and constant population composition, immigrants were more likely to choose such occupations in 2010-2012 than in 1994-1996. The right-hand panel of Figure 7 shows that the probability of natives choosing occupations showing a higher within-occupation wage change increased, while the corresponding probability among immigrants decreased. This pattern persists, although clearly smoothed, after controlling for population composition effects. Overall, immigrants' and natives' occupational choices differed despite identical changes in returns to skills.

\section{INSERT FIGURE 6}

\subsubsection{Characterizing the quantity effect: the role of tasks}

Next we relate occupational choices to the task content of occupations. Differing occupational choices across nativity groups result from different changes in comparative advantage, which are related to different changes in 
skill endowment. ${ }^{41}$ Our analysis focuses on the coefficients associated with the interaction terms Year $\times$ Tas $_{j}$, which capture changes over time in the probability of choosing an occupation relatively more intensive in the corresponding task. To take into account inter-occupational differences in probability of exposure to a minimum wage change, we also control for the share of minimum wage earners. ${ }^{42}$

Figure 7 displays on the $\mathrm{X}$-axis the 10th, 25th, 50th, 75th and 90th percentiles of the intensity index distribution for each task and on the Y-axis the variation (between $1994-96$ and 2010-12) in the probability of choosing an occupation located at the corresponding percentile of each task category. An upward (downward) profile in Figure 7 along the task intensity index distribution indicates that occupations relatively more intensive in the corresponding task are more (less) likely to be chosen over time. These graphs show the type of tasks in which immigrants and natives have become increasingly concentrated and therefore reveal how the pattern of their comparative advantages has evolved over time. Again, solid curves represent the results for the observed population sample while dashed curves represent a constant population composition over time and across nativity groups (in terms of age, education and length of residence). Dashed curves will reveal then whether differences in occupational mobility are due to genuinely different comparative advantages within age*education skill groups or are due to standard differences in observable age*education characteristics. ${ }^{43}$

\section{INSERT FIGURE 7}

The left-hand panel displays the predicted change (from 1994-1996 to 2010-2012) in probability of choosing an occupation along the distribution of the non-routine manual task index. The probability that immigrants will choose an occupation more intensive in non-routine manual tasks has declined over time. Instead, there is a weakly increasing probability of natives choosing occupations more intensive in non-routine manual tasks. Controlling for changes and differences in population composition does not affect this pattern. Therefore, relative to natives, immigrants are losing comparative advantage in non-routine manual tasks. Immigrants seem to have moved away from non-routine manual-task-intensive occupations. This pattern of mobility is consistent with the decreasing wage dispersion estimated for immigrants in Table 1 in occupations requiring non-manual skills. ${ }^{44}$

The middle panel of Figure 7 displays changes in the probability of choosing an occupation depending on its intensity in routine tasks. Natives seem to have moved away from routine task-intensive occupations; immigrants have too, but to a much lower extent. The pattern and the difference between the two nativity groups are explained

\footnotetext{
${ }^{41}$ Our approach is similar to that adopted in the microeconomic literature on revealed preferences. Taking as given changes in returns to skills, we infer immigrants' and natives' changes in relative skill endowment by looking at differences in their reaction to changes in the pricing of skills. Our approach is also related to that of Basso, Peri, and Rahman (2017) for US data or Adsera and Ferrer (2014) for Canadian data, who provide a descriptive analysis of the evolving supply of analytical, routine and manual tasks by immigrants and natives inferred from their distribution among occupations over time.

${ }^{42}$ The extent to which immigrants and natives are attracted by occupations whose wage changes are closely related to minimum wage changes may differ if, owing to specific characteristics, their likelihood of being minimum wage earners differs. This feature is particularly relevant in the French context, where the minimum wage level increased sharply over the period.

${ }^{43}$ For instance, the fact that more educated workers may have a comparative advantage in less routine occupations.

44 In contrast to our findings, Basso, Peri, and Rahman (2017) show that in the US since 1980 immigrants have become relatively more concentrated in non-routine manual tasks than natives, who have become concentrated in non-routine analytical tasks. These differences with respect to our findings may be due to both differences in the composition of the pool of immigrants in France and the US (in terms of qualifications, countries of origin, length of residence or age), and, on the demand side, differences in the dynamics of the occupational structure in France and the US.
} 
by changes and differences in the composition of the populations. At constant and identical population composition, we find that natives are more likely than immigrants to choose routine occupations. Therefore, under identical characteristics, natives have gained comparative advantage in these occupations. Combined with the left-hand panel of the figure, this suggests that despite their departure from non-routine manual-task-intensive occupations, immigrants do not seem to be streaming towards routine-task-intensive occupations. This is consistent with estimations in Figure 6. Over the past decades, immigrants have increasingly shifted towards occupations experiencing high between-occupation wage change (i.e. high average wage growth). Recent technological changes have promoted a relative decrease in the price of routine-task-intensive goods (see Autor, Levy, and Murnane (2003), Autor, Levy, and Kearney (2006), Goos and Manning (2007), Spitz-Oener (2006) or Maurin and Thesmar (2004)) implying a reduced average wage growth in routine-task-intensive occupations. Immigrants have thus drifted away from this type of occupation.

The right-hand panel of Figure 7 displays the predicted change in probability of choosing an occupation depending on its relative intensity in non-routine abstract tasks. Occupations more intensive in non-routine abstract tasks are increasingly likely to be chosen by both immigrants and natives, although for natives this is mainly due to specialization in abstract tasks with increasing experience (proxied here by age) and education. When composition effects are removed, we find that the probability of natives choosing occupations more intensive in non-routine tasks has only slightly increased. In contrast, under a similar and constant population composition, we observe greater specialization of immigrants in non-routine abstract-task-intensive occupations, which appears to have given them a comparative advantage in occupations. ${ }^{45}$

Figures 6 and 7 combined portray an immigrant population that has experienced upward occupational mobility relative to natives and has moved towards occupations offering the highest increase in average wage. Between 1994-96 and 2010-12, immigrants were upgrading from the lower (manual tasks) to the upper part (non-routine abstract tasks) of the wage distribution.

\section{Conclusions}

Using the French Labor Force Survey, the EurOccupations and O*NET datasets, we analyzed two crucial sources of immigrants' labor market performance: immigrants' skills and how these skills are valued. Although they are non-observable, we were able to assess changes in immigrants' and natives' relative skill endowments along dimensions that have so far been overlooked in the literature. These endowments are related to task-specific returns to skills.

French immigrants' wage growth is shown to have outperformed that of natives throughout the wage distribution over the period 1994-2012. While a substantial part of immigrants' wage growth is due to their specific characteristics, we show that immigrants also accumulated skills that are more highly rewarded as they moved up the occupational wage ladder. In particular, their pattern of occupational sorting over the period suggests that they

\footnotetext{
45 This result is particularly interesting since it sharply contrasts with the findings of other papers dealing with migration in the US (see Peri and Sparber (2011b), Peri and Sparber (2011a), Peri and Sparber (2009), D’Amuri and Peri. (2014)) or Basso, Peri, and Rahman (2017).
} 
moved upward in the occupational wage distribution towards high-wage-growth occupations faster than natives.

Though not unequivocal, our results show that the relative "labor market quality" of immigrants has improved over the last two decades in France. Interestingly, this improvement is the consequence not only of changes in the market reward for skills but potentially also of immigrants' human capital adjustment. Overall, it seems that immigrants have been able to better price their skills by moving across tasks. We hope to confirm these patterns in future research by investigating, using individual panel data, how the dynamics of wages and human capital adjustments are driven by globalization and technological changes. In addition, while this paper focuses on male earnings, taking gender differences into account would be a worthwhile complement to the present research.

\section{FIGURES}

Figure 1: Average yearly employment and wage growth over the 1994 median wage in the occupation. French LFS 1994-2012
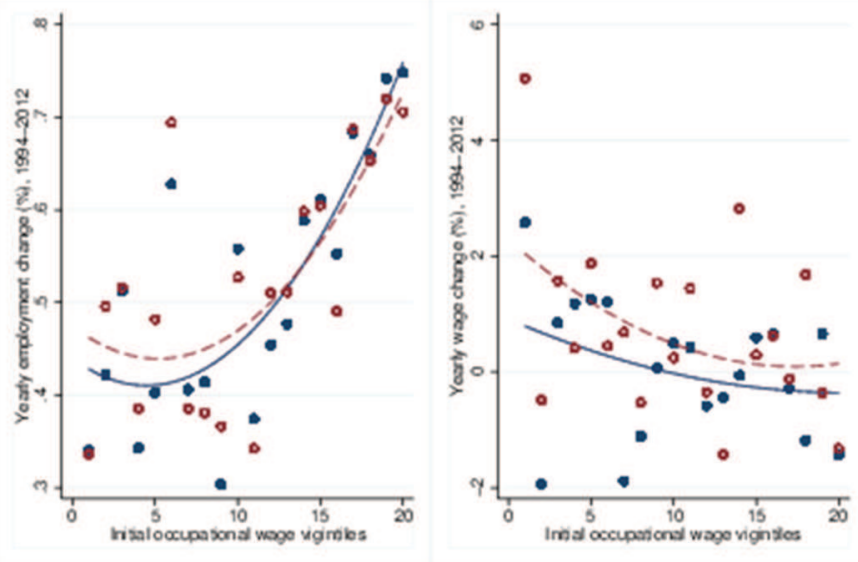

- Natives

Fitted values o Immigrants

Fitted values

Notes: Occupations are ranked in the X-axis in ascending order according to their median real wage in 1994, computed on native full-time equivalent workers, and then grouped within occupational wage vigintiles. The Y-axis in the left-hand panelrepresentsyearlyaverageemploymentgrowthbetween 1994and2012byvigintile, whileintheright-hand padit represents the yearly average real wage growth by vigintile over the same period.

Figure 2: Intensity, along the skill distribution, of immigrants' and natives' occupational employment in nonroutine manual tasks in 1994 


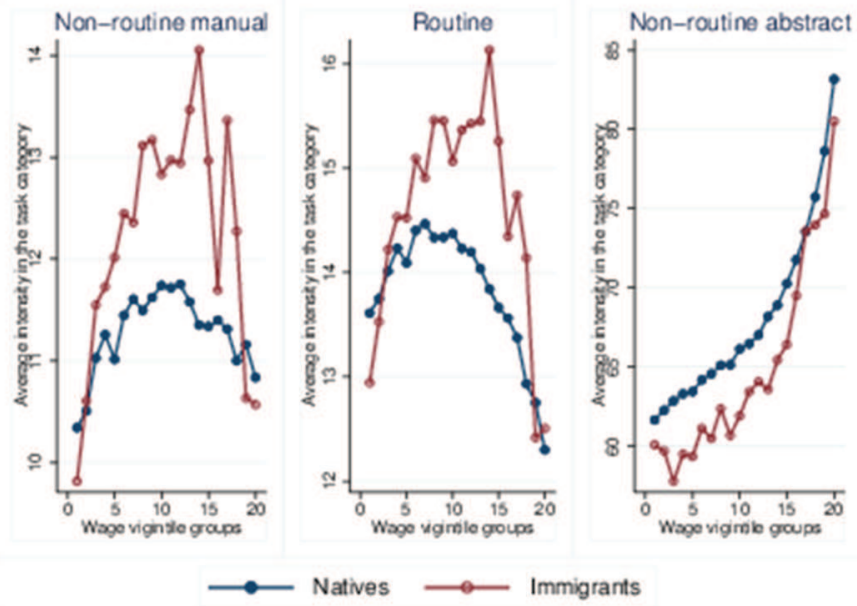

Notes: Observations for immigrant and native samples are ranked in the $\mathrm{X}$-axis according to their wage vigintile group (20 groups) computed overthe wage distribution of natives in 1994 . The Y-axis represents the weighted average of immigrant and native occupational employment intensity in the given task category within each vigintile group. The weights are equal to the share of each occupation in the total employment of the corresponding wage vigintile group, computed separately for immigrants and natives.

Figure 3: Variation in task intensity of immigrant and native occupational employment between 1994-1996 and 2010-2012
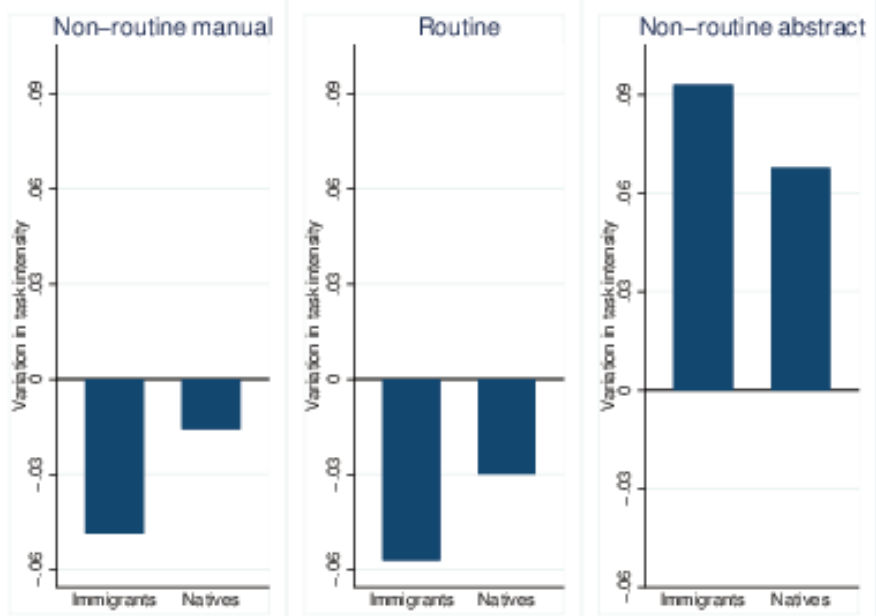

Notes: The Y-axis represents the change between $\mathrm{t} 2=2010-2012$ and $\mathrm{t} 1=1994-1996$ in average intensity for each task $k$. For every period $t$ the average intensity of immigrants or natives in task $\mathrm{k}$ is :Task $k_{k t}=\sum_{j}^{J} \operatorname{share}_{j t} * \operatorname{Task}_{j k}$, where share $_{j t}$ is equal to the share of occupation $j$ among natives or immigrants, and $T_{a s} k_{j k}$ is the ONET intensity of occupation $j$ in task $k=(1)$ non-routine abstract, (2) non-routine manual or (3) routine task. The graph represents the variation in this index between the last and first period.

Figure 4: Wages and skill returns

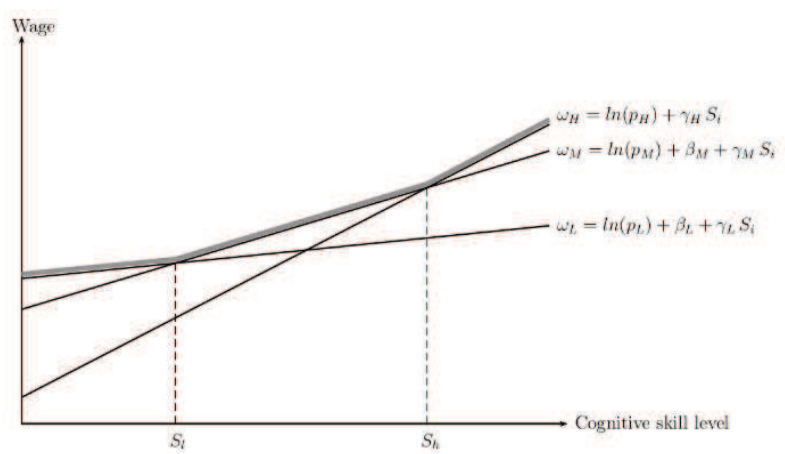

Figure 5: The between- and within-occupation components of wage changes for natives and immigrants. Constant population composition. 


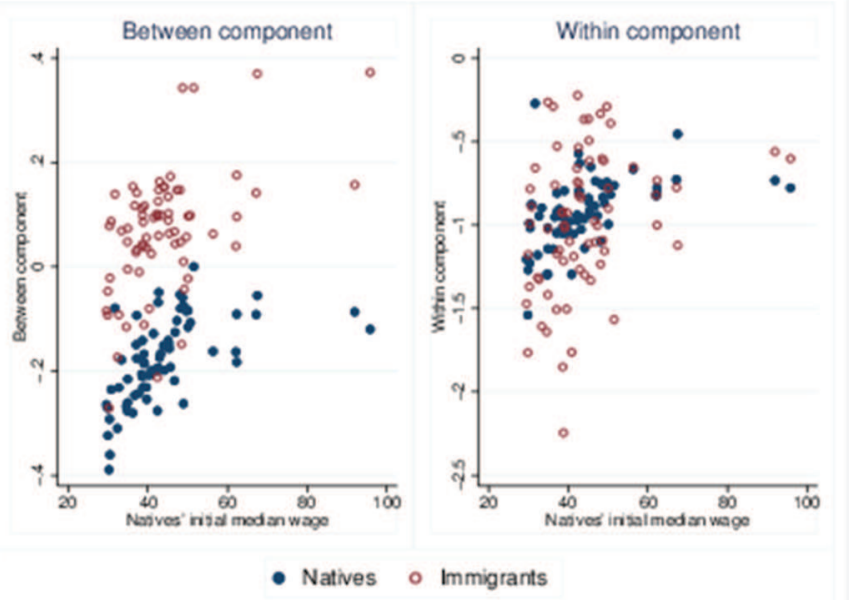

Notes: Natives' residual wages were computed by including in the wage equation a full set of age*education dummies, while immigrants' residual wages were computed by including in the wage equation a full set of age*education*residence duration dummies and 27 country of origin dummies. The betweenand within-occupation components of wage changes were estimated using changes in residual wage deciles in each occupation as dependent variable. In the $\mathrm{X}$-axis the same 124 occupations for immigrants and natives are ranked according to their median wage computed over the wage distribution of natives in the baseline period (1994-96). In the X-axis occupations are ranked according to their median wage computed over the wage distribution of natives in the baseline period (1994-96). The age*education composition within occupations is kept constant and equal to that of natives in the baseline period for both immigrants and natives. For immigrants, length of residence composition is also kept equal to that observed in the baseline.

Figure 6: Change in probability of choosing an occupation according to wage changes between 1994-1996 and 20102012



Notes: The X-axis represents the 10th, 25th, 50th, 75th and 90th percentiles of the between-occupation coefficient distribution for the left-hand panel and of the within-occupation coefficient distribution for the right-hand panel. The between- and within-occupation components we consider here are those estimated from equation (6) for each occupation on the sample of natives, removing age-education composition effects. In the Y-axis, using coefficient estimates from the conditional logit, we report the predicted change from period 1 to period 2 in probability of choosing an occupation located at the corresponding percentile of the distribution of the between-occupation or within-occupation coefficients. The shadowed area corresponds to the $95 \%$ confidence interval.

Figure 7: Change in probability of choosing an occupation according to intensity in each task category 

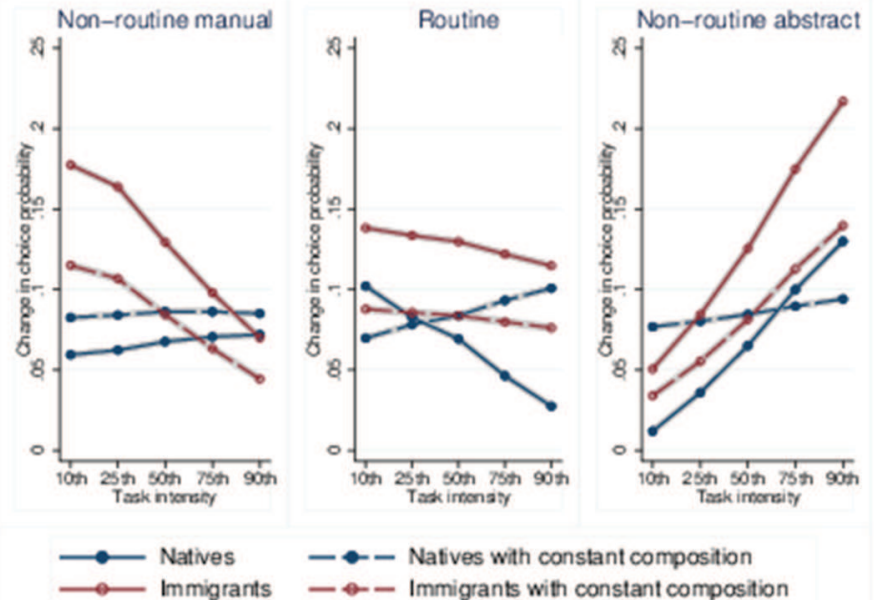

\section{- Nafives with constant composition}

Notes: The X-axis represents the 10th, 25th, 50th, 75th and 90th percentiles of the corresponding task intensity index distribution. The task percentiles were computed over the natives' occupational employment distribution in the baseline (1994-1996). In the Y-axis, using coefficient estimates from the conditional logit, we report the predicted change from period 1 to period 2 in probability of choosing an occupation located at the corresponding percentile of the task intensity index. The shadowed area corresponds to the $95 \%$ confidence interval. 


\section{TABLES}

Table 1: Task contribution to between- and within-occupation wage changes, from 1994-96 to 2010-12. Natives vs. Immigrants.

Dependent variables: Between- and within-occupation wage changes

\begin{tabular}{|c|c|c|c|c|c|c|}
\hline \multirow[b]{2}{*}{ Scenarios } & \multicolumn{3}{|c|}{ Between-occupation wage change } & \multicolumn{3}{|c|}{ Within-occupation wage change } \\
\hline & Baseline & Weight 1 & Weight 2 & Baseline & Weight 1 & Weight 2 \\
\hline & (1) & (2) & (3) & (4) & (5) & (6) \\
\hline \multirow[t]{2}{*}{ Immigrant } & $0.209 * * *$ & $0.438 * * *$ & $0.238 * * *$ & -0.0477 & $0.432 * * *$ & 0.0529 \\
\hline & $(0.0571)$ & $(0.0614)$ & $(0.0507)$ & $(0.113)$ & $(0.158)$ & $(0.197)$ \\
\hline \multirow[t]{2}{*}{ Non-routine abstract } & $0.159 * * *$ & $0.124 * *$ & 0.0637 & $0.353 * * *$ & $0.419 * * *$ & $0.296^{*}$ \\
\hline & $(0.0484)$ & $(0.0478)$ & $(0.0454)$ & $(0.114)$ & $(0.149)$ & $(0.156)$ \\
\hline \multirow{2}{*}{ Routine } & $-0.272 * * *$ & $-0.159 * * *$ & $-0.180 * * *$ & $-0.581 * * *$ & $-0.396 * *$ & $-0.459 * * *$ \\
\hline & $(0.0688)$ & $(0.0588)$ & $(0.0587)$ & $(0.161)$ & $(0.178)$ & $(0.173)$ \\
\hline \multirow[t]{2}{*}{ Non-routine manual } & $0.302 * * *$ & $0.205^{* * *}$ & $0.270 * * *$ & $0.272 * *$ & $0.230^{*}$ & $0.363 * * *$ \\
\hline & $(0.0597)$ & $(0.0509)$ & $(0.0530)$ & $(0.112)$ & $(0.119)$ & $(0.111)$ \\
\hline \multirow[t]{2}{*}{ Immigrant*Non-routine abstract } & 0.130 & 0.0598 & 0.0749 & -0.109 & -0.262 & -0.0480 \\
\hline & $(0.0976)$ & $(0.182)$ & $(0.0768)$ & $(0.220)$ & $(0.304)$ & $(0.303)$ \\
\hline \multirow[t]{2}{*}{ Immigrant*Routine } & -0.0642 & 0.0667 & 0.0645 & $0.433 *$ & $0.812 * * *$ & 0.431 \\
\hline & $(0.113)$ & $(0.156)$ & $(0.0844)$ & $(0.251)$ & $(0.276)$ & $(0.326)$ \\
\hline \multirow[t]{2}{*}{ Immigrant*Non-routine manual } & 0.0869 & -0.110 & -0.0773 & $-0.382 *$ & $-0.928 * * *$ & $-0.551^{*}$ \\
\hline & $(0.117)$ & $(0.181)$ & $(0.0875)$ & $(0.222)$ & $(0.317)$ & $(0.290)$ \\
\hline \multicolumn{7}{|l|}{ Population composition constant } \\
\hline within groups & NO & YES & YES & NO & YES & YES \\
\hline within and across groups & NO & NO & YES & NO & NO & YES \\
\hline Control for length of residence & NO & YES & YES & NO & YES & YES \\
\hline Observations & 248 & 162 & 144 & 248 & 162 & 144 \\
\hline R-squared & 0.530 & 0.767 & 0.687 & 0.190 & 0.266 & 0.124 \\
\hline
\end{tabular}

Notes: Robust standard errors in parentheses. Statistical significance: $* * * p<0.01, * * p<0.05, * p<0.1$. In all regressions we control for an occupation-specific labor demand shift index (see text for details). Regressions are weighted using the initial period employment level. In all columns, natives' wage residuals are computed by including in the wage equation a full set of age*education dummies. In all columns, immigrants' wage residuals are computed by including in the wage equation a full set of age*education*(residence duration) dummies and 27 country of origin dummies. In weighting scenario Weight 1 , population composition within occupations is kept constant, as in the baseline for each nativity group. In weighting scenario Weight 2, population composition within occupations is kept constant, and the baseline population composition of natives is applied to both immigrants and natives. In columns (2), (3), (5) and (6) the control for population composition effects includes immigrants' length of residence.

\section{References}

Acemoglu, D., and D. Autor. 2011. "Skills, Tasks and Technologies: Implications for Employment and Earnings." In Handbook of Labor Economics, edited by Orley Ashenfelter and David E. Card, Volume 4. Amsterdam: Elsevier. Adsera, Alicia, and Ana M. Ferrer. 2014. "The Myth of Immigrant Women as Secondary Workers: Evidence from

Canada." American Economic Review 104 (5): 360-364 (May).

Algan, Y., C. Dustmann, A. Glitz, and A. Manning. 2010. "The Economic Situation of First and Second Generation Immigrants in France, Germany and UK." Economic Journal 120 (542): 4-30.

Amuedo-Dorantes, C., and S. De La Rica. 2011. "Complements or Substitutes? Task Specialization by Gender and Nativity in Spain." Labour Economics 18 (5): 697-707.

Atalay, E., P. Phongthiengtham, S. Sotelo, and D. Tannenbaum. 2018. The Evolving U.S. Occupation Structure.

Autor, D., and D. Dorn. 2013. "The Growth of Low-Skill Service Jobs and the Polarization of the U.S. Labor Market." American Economic Review 103 (5): 1553-1597.

Autor, D., and M. J. Handel. 2013. "Putting Tasks to Test: Human Capital, Job Tasks, and Wages." Journal of Labor Economics 31:S59-S96.

Autor, D., L. Katz, and M. Kearney. 2008. "Trends in the U.S. Wage Inequality: Re-Assessing the Revisionists.” Review 
of Economic and Statistics 90:300-323.

Autor, D., F. Levy, and M. Kearney. 2006. "The Polarization of the US Labor Market.” American Economic Review 96 (2): 189-194.

Autor, D., F. Levy, and R. Murnane. 2003. "The Skill Content of Recent Technological Change: An Empirical Exploration." Quarterly Journal of Economics 118 (4): 1279-1333.

Barth, E., B. Bratsberg, and O. Raaum. 2012. "Immigrant Wage Profiles Within and Between Establishments." Labour Economics 19 (4): 541-556.

Bartik, T. 1991. "Who Benefits from State and Local Economic Development Policies?” Technical Report, W.E. Upjohn Institute for Employment Research.

Basso, G., G. Peri, and A. Rahman. 2017. "Computerization and Immigration: Theory and Evidence from the United States.” Working paper 23935, National Bureau of Economic Research.

Bertrand, M., E. Duflo, and S. Mullainathan. 2004. "How Much Should We Trust Differences-in-Differences Estimates?" Quarterly Journal of Economics 119 (1): 249-275.

Borjas, G. 1994. “The Economics of Immigration.” Journal of Economic Literature XXXII:1667- 1717. . 1995. "Assimilation and Changes in Cohort Quality Revisited: What Happened to Immigration Earnings in the 1980s?" Journal of Labor Economics 13 (21): 201-245. 1999. "Immigration and Welfare Magnets." Journal of Labor Economics 17 (4): 607-637. 2003. "The Labor Demand Curve is Downward Sloping: Reexamining the Impact of Immigration on the Labor Market." Quarterly Journal of Economics 118 (4): 1335-1374.

Boudarbat, B., and T. Lemieux. 2014. "Why Are the Relative Wages of Immigrants Declining? A Distributional Approach." Industrial and Labor Relations Review 67 (4): 1127-1165.

Card, D. 2005. "Is the New Immigration Really So Bad?" Economic Journal 115 (507): 300-323.

Chassamboulli, A., and G. Peri. 2014. "The Labor Market Effects of Reducing Undocumented Immigrants." Mimeo. Chiswick, R.B. 1978. "The Effects of Americanization on Foreign-Born Men." Journal of Political Economy 86:81-87. Chiswick, R.B., Y. Lee, and P. Miller. 2005. "Immigrant Earnings: A Longitudinal Analysis." Review of Income and Wealth 51:485-503.

Cortes, G.M. 2016. "Where Have the Middle-Wage Workers Gone? A Study of Polarization Using Panel Data." Journal of Labor Economics 34 (1): 63-105.

D'Amuri, F., and G. Peri. 2014. "Immigration, Jobs, And Employment Protection: Evidence from Europe Before And During The Great Recession." Journal of the European Economic Association 12 (2): 432-464.

DiNardo, J., N. M. Fortin, and T. Lemieux. 1996. "Labor Market Institutions and the Distribution of Wages, 1973-1992: A Semiparametric Approach.” Econometrica 64 (5): 1001-1044.

Dustmann, C., T. Frattini, and I. Preston. 2013. "The Effect of Immigration along the Distribution of Wages." Review of Economic Studies 80 (1): 145-173.

Edo, A., and F. Toubal. 2015. "Selective Immigration Policies and Wages Inequality." Review of International Economics 23 (1): 160-187. 2017. "Immigration and the Gender Wage Gap." European Economic Review 92 (2): 196-214.

Friedberg, R. 2000. "You Can't Take It With You? Immigrant Assimilation and the Portability of Human Capital." Journal of Labor Economics 18 (2): 221-251.

Friedberg, R., and J. Hunt. 1995. "The Impact of Immigration on Host Wages, Employment and Growth." Journal of Economic Perspectives IX:23-44.

Gibbons, R., L.F. Katz, T. Lemieux, and D. Parent. 2005. "Comparative Advantage, Learning, and Sectoral Wage Determination." Journal of Labor Economics 23 (4): 681-724. 
Gonzalez, L., and F. Ortega. 2011. "How Do Very Open Economies Absorb Large Immigration Flows? Recent Evidence from Spanish Regions." Labour Economics 18:57-70.

Goos, M., and A. Manning. 2007. "Lousy and Lovely Jobs: the Rising Polarization of Work in Britain." Review of Economics and Statistics 89 (1): 118-133.

Imai, S., Derek S., and C. Warman. 2019. "From Engineer to Taxi Driver? Occupational Skills and the Economic Outcomes of Immigrants." Canadian Journal of Economics, Forthcoming.

Katz, L., and K. Murphy. 1992. "Changes in Relative Wages, 1963-1987: Supply and Demand Factors." Quarterly Journal of Economics 107:35-78.

Kee, P. 1995. "Native-Immigrant Wage Differentials in the Netherlands: Discrimination?" Oxford Economic Papers 47 (2): 302-317.

Laffineur, C., and E. M. Mouhoud. 2015. "The jobs at Risk from Globalization: the French Case." Review of World Economics 151 (3): 477-531.

Lam, K.C., and P.W. Liu. 2002. "Earnings Divergence of Immigrants." Journal of Labor Economics 20:86-101.

Lazear, E.P. 2009. "Firm's Specific Human Capital: A Skill Weights Approach.” Journal of Political Economy 117 (5): 914-940.

Lemieux, T. 2002. "Decomposing changes in wage distributions: a unified approach." Canadian Journal of Economics 35:646-688.

Lewis, E. 2013. In Immigrant Native Substitutability: The Role of Language. David Card and Stephen Raphael, eds, New York: Russell Sage Foundation.

Lewis, J. B., and D. A. Linzer. 2005. "Estimating Regression Models in Which the Dependent Variable Is Based on Estimates." Political Analysis 13 (4): 345-364.

Lubotsky, Darren. 2011. "The Effect of Changes in the U.S. Wage Structure on Recent Immigrants' Earnings." Review of Economics and Statistics 93 (1): 59-71.

Maddala, G. S. 2001. Introduction to Econometrics. 3rd. West Sussex: John Wiley and Sons.

Manacorda, M., A. Manning, and J. Wadsworth. 2012. "The Impact of Immigration on the Structure of Male Wages: Theory and Evidence from Britain." Journal of the European Economic Association 10 (1): 120-151.

Maurin, E., and D. Thesmar. 2004. "Changes in the Functional Structure and Demand for Skills." Journal of Labor Economics 22 (3): 639-664.

McFadden, D. 1974. Chapter "Conditional Logit Analysis of Qualitative Choice Behavior" of Frontiers in Econometrics, edited by P. Zarembka, 105-142. New York: Academic Press.

Mitaritonna, C., G. Orefice, and G. Peri. 2017. “Immigration and Firms' Outcomes: Evidence from France.” European Economic Review 96:62-82.

Moreno-Galbis, E., and A. Tritah. 2016. "The Effects of Immigration in Frictional Labor Markets: Theory and Empirical Evidence from EU Countries." European Economic Review 84: 76-98.

Nanos, P., and C. Schluter. 2014. "The composition of wage differentials between migrants and natives." European Economic Review 65:23-44.

Ortega, J. 2000. "Pareto-Improving Immigration in an Economy with Equilibrium Unemployment." Economic Journal 110 (460): 92-112.

Ortega, J., and G. Verdugo. 2014. "Immigration and the Occupational Choice of Natives: A Factor Proportions Approach." Labour Economics 29:14-27.

Ottaviano, G., and G. Peri. 2012. "Rethinking the Effects of Immigration on Wages." Journal of the European Economic Association 10 (1): 152-197.

Peri, G., and C. Sparber. 2009. “Task Specialization, Immigration, and Wages.” American Economic Journal: Applied 
Economics 1 (3): 135-169.

.2011a. "Assessing Inherent Model Bias: An Application to Native Displacement in Response to Immigration." Journal of Urban Economics 69 (1): 82-91.

2011b. "Highly-Educated Immigrants and Native Occupational Choice." Industrial Relations 50 (3): 385411.

Roy, A. D. 1951. "Some Thoughts on the Distribution of Earnings." Oxford Economic Papers 3 (2): 135-146.

Spitz-Oener, A. 2006. "Technical Change, Job Tasks and Rising Educational Demands: Looking Outside the Wage Structure." Journal of Labor Economics 24 (2): 235-270.

Tidjens, K., E. De Ruijter, and J. De Ruikter. 2011. "Inside occupations: comparing the task description of 160 occupations across eight EU member states." Technical Report, ISOL.

Warman, C., and C. Worswick. 2015. "Technological change, occupational tasks and declining immigrant outcomes: Implications for earnings and income inequality in Canada." Canadian Journal of Economics 48 (2): 736-772.

White, H. 1980. "A Heteroskedasticity-Consistent Covariance Matrix Estimator and a Direct Test for Heteroskedasticity." Econometrica 48 (4): 817-838.

Yamaguchi, S. 2010. "Career Progression and Comparative Advantage." Labour Economics 17 (4): 679-89.

.2018. "Changes in Returns to Task-Specific Skills and Gender Wage Gap." Journal of Human Resources 53 (1): $32-70$. 


\section{Appendices}

\section{A Databases}

\section{A.1 Sample Characteristics}

Table 2: Sample characteristics per year, French LFS 1993-2012.

\begin{tabular}{l|c|c|c|c|c|c|c|c|c}
\hline \hline & $\mathrm{N}$ & $\begin{array}{c}\text { Immigrants } \\
(\%)\end{array}$ & $\begin{array}{c}\text { Age } \\
\text { immigrants }\end{array}$ & $\begin{array}{c}\text { Age } \\
\text { natives }\end{array}$ & $\begin{array}{c}\text { Education } \\
\text { immigrants }\end{array}$ & $\begin{array}{c}\text { Education } \\
\text { natives }\end{array}$ & $\begin{array}{c}\text { Wage } \\
\text { immigrants }\end{array}$ & $\begin{array}{c}\text { Wage } \\
\text { natives }\end{array}$ & $\begin{array}{c}\text { Years of } \\
\text { residence }\end{array}$ \\
\hline 1993 & 39515 & 11.05 & 40,46 & 37,13 & 1,52 & 1,55 & 1326,45 & 1382,38 & 18,51 \\
1994 & 40059 & 11.23 & 41,04 & 37,34 & 1,51 & 1,56 & 1542,84 & 1597,94 & 19,12 \\
1995 & 40814 & 11.39 & 41,05 & 37,46 & 1,53 & 1,59 & 1389,61 & 1308,82 & 18,66 \\
1996 & 41186 & 11.41 & 41,43 & 37,63 & 1,59 & 1,60 & 1539,49 & 1341,79 & 18,94 \\
1997 & 40505 & 11.31 & 41,66 & 37,86 & 1,60 & 1,64 & 1211,57 & 1322,40 & 19,30 \\
1998 & 41070 & 11.03 & 41,73 & 37,94 & 1,59 & 1,66 & 1217,72 & 1234,47 & 19,46 \\
1999 & 41969 & 11.23 & 42,11 & 37,94 & 1,62 & 1,69 & 1282,79 & 1239,60 & 19,83 \\
2000 & 35922 & 10.66 & 41,95 & 37,84 & 1,68 & 1,71 & 1261,94 & 1297,84 & 21,87 \\
2001 & 43525 & 11.33 & 42,51 & 38,02 & 1,66 & 1,75 & 1342,89 & 1356,46 & 19,33 \\
2002 & 43287 & 10.82 & 42,53 & 38,22 & 1,69 & 1,78 & 1292,65 & 1299,52 & 19,28 \\
2003 & 25950 & 10.52 & 42,43 & 38,22 & 1,77 & 1,84 & 1454,25 & 1513,18 & 25,41 \\
2004 & 24694 & 10.74 & 41,96 & 37,97 & 1,83 & 1,90 & 1496,39 & 1509,01 & 25,05 \\
2005 & 26256 & 10.36 & 42,34 & 38,46 & 1,89 & 1,92 & 1430,54 & 1498,26 & 25,26 \\
2006 & 26068 & 10.55 & 42,60 & 38,64 & 1,88 & 1,93 & 1431,43 & 1501,69 & 25,51 \\
2007 & 27423 & 10.99 & 42,43 & 38,69 & 1,89 & 1,97 & 1401,80 & 1519,42 & 25,13 \\
2008 & 27995 & 11.57 & 42,49 & 38,79 & 1,93 & 2,01 & 1448,50 & 1509,25 & 24,52 \\
2009 & 32348 & 11.39 & 42,75 & 39,24 & 1,97 & 2,03 & 1465,90 & 1559,08 & 24,78 \\
2010 & 37169 & 11.51 & 42,66 & 39,59 & 1,96 & 2,06 & 1477,09 & 1557,79 & 24,44 \\
2011 & 39598 & 11.36 & 43,10 & 39,75 & 2,00 & 2,09 & 1502,33 & 1566,87 & 24,87 \\
2012 & 39553 & 11.54 & 43,21 & 40,36 & 2,03 & 2,11 & 1525,00 & 1567,49 & 24,48 \\
\hline \hline
\end{tabular}

Notes: French Labor Force Survey 1993-2012. Individuals in the private sector declaring a strictly positive wage. Education: "1: Less than secondary education, 2: Secondary education, 3: Baccalaureate+2 years, 4: University studies". Real wages in euros. For the period 1994-2002 there are only 11,187 immigrants whose date of entry to France is known; this rises to 77,316 immigrants for the period 2003-2012. This probably explains the shift in length of residence observed from 2003.

Table 3: Population composition by nativity group, French LFS 1993-2012.

\begin{tabular}{l|c|c}
\hline \hline & Frequency & Share (\%) \\
\hline French & 635277 & 89.41 \\
North African & 26842 & 3.78 \\
African & 9291 & 1.31 \\
South-Eastern Asian & 3083 & 0.43 \\
South-European & 20609 & 2.90 \\
North-European & 6984 & 0.98 \\
East-European and & & \\
Russian & 5334 & 0.75 \\
South-American & 1561 & 0.22 \\
North American & 264 & 0.04 \\
Turkish & 1287 & 0.18 \\
\hline Total & 710532 & 100 \\
\hline \hline
\end{tabular}

Notes: French Labor Force Survey 1993-2012. Individuals in the private sector declaring a strictly positive wage. There are 4374 observations for which the countyof origin is unknown. 


\section{A.1 Occupational task composition}

Table 4: Occupational tasks.

\begin{tabular}{l|l}
\hline Non-routine Analytical & $\begin{array}{l}\text { Organizing, Planning, and Prioritizing Work; Getting Information; Analyzing Data or in- } \\
\text { formation; Making Decisions and Solving Problems; Developing Objectives; Judging the Qualities of Things, } \\
\text { Services, orPeople;Updating and Using Relevant Knowledge;Inter- acting with Computers ; Thinking Creatively } \\
\text {; Estimating the Quantifiable Characteristics of Products, Events, or Information ; Evaluating Information to } \\
\text { Determine Compliance with Standards; Scheduling Work and Activities; Interpreting the Meaning of Information } \\
\text { for Others ; Processing Information and Strategies. }\end{array}$ \\
\hline Non-routine Inter-personal & $\begin{array}{l}\text { Guiding, Directing, and Motivating Subordinates; Communicating with Supervisors, Peers, } \\
\text { or Subordinates ; Communicating with Persons Outside the Organization ; Developing and Building Teams; } \\
\text { Resolving Conflicts and Negotiating with Others ; Performing for or Working Directly with the Public; Staffing } \\
\text { Organizational Units Providing Consultation and Advice to Others ; Coordinating the Work and Activities of } \\
\text { Others; Selling or Influencing Others } \\
; \text { Training and Teaching Others; Assisting and Caring for Others; Coaching and Developing Others; Establishing } \\
\text { and Maintaining Interpersonal Relationships; Monitoring and } \\
\text { Controlling Resources. }\end{array}$ \\
\hline Routine Cognitive & $\begin{array}{l}\text { Performing Administrative Activities, Documenting/Recording Information. } \\
\text { Equipment; Repairing and Maintaining Electronic Equipment. }\end{array}$ \\
\hline Routine Manual & $\begin{array}{l}\text { Operating Vehicles, Mechanized Devices, or Equipment; Inspecting Equipment, Structures, or Material; Monitoring } \\
\text { Processes, Materials, or Surroundings; Drafting, Laying Out, and Specifying Technical Devices, Parts, and } \\
\text { Equipment. }\end{array}$ \\
\hline Non-routine Manual &
\end{tabular}

Source: Constructed using data from O*NET.

\section{B Removing composition effects in wage changes}

In order to capture the precise contribution of tasks to the estimated residual wage differentials between 1994-1996 and 2010-2012, we remove the proportion of the residual wage change resulting from changes in worker composition in terms of age, education and length of residence. We successively propose two alternative scenarios keeping the age-education-length of residence composition of occupations constant in both periods, but either considering each nativity group separately or taking natives as reference.

\section{B.1 A cell-by-cell approach}

We rely on the cell-by-cell approach suggested by Lemieux (2002), which is equivalent to the reweighting method of DiNardo, Fortin, and Lemieux (1996) but more flexible. This non-parametric procedure consists in first dividing the data into a limited number $C$ of cells, in each occupation $j$ and at each period $t$, according to a set of dummy variables $x_{i j t}=\left(x_{i 1 j t}, \ldots, x_{i c j t}, \ldots, x_{i c j t}\right)$. This procedure is based on the definition of the same age-education cells for natives and the same age-education-length of residence cells for immigrants within each occupation. We keep only cells that are observed in both periods to ensure consistency when applying this reweighting method.

For both native and immigrant workers, we use the following dummies to define age-education cells: we consider 9 distinct 5-year interval age groups (from 15 to 60), and within each age group we distinguish 4 education levels (below baccalaureate, baccalaureate or equivalent, baccalaureate +2 years, higher degree). For immigrant workers, we additionally distinguish within each age-education cell two lengths of residence: less than 10 years or 10 years and more. Thus, we can define up to 36 age-education cells for natives and up to 72 age-education-length of residence cells for immigrants. Age is often used to proxy actual work experience in the literature. An alternative would be to use potential work experience, which is, under the standard assumption, equal to the worker's age 
minus the typical age at which she is expected to have completed her education ${ }^{46} \mathrm{~A}$ caveat to using such proxies is that actual work experience is measured with error, except for individuals who work full-time and continuously. When work experience is acquired immediately after schooling, potential experience and actual experience coincide. In contrast, potential experience may be a noisy proxy of actual experience for women or immigrants (see Barth, Bratsberg, and Raaum (2012)).

For each cell $c$, in occupation $j$ and at period $t$, we then estimate a reweighting factor $\Psi_{c j t}$ that will be used to calculate a counterfactual sample weight: $\omega_{c j t}^{a}=\Psi_{c j t} \omega_{c j t}$, where $\omega_{c j t}$ is the original sample weight of cell $c$, in occupation $j$ and period $t$. The reweighting factor of each cell $c$ is built up first from the sample share of workers in the cell (natives or immigrants), in occupation $j$ and period $t$, denoted $\eta_{c j t}$, which is given by the sample average of the dummy variable $x_{i c t}$ :

$\overline{x_{c j t}}=\sum_{i} \omega_{i t} x_{i c j t}=\sum_{x_{i c j t}} \omega_{i t}=\eta_{c j t}$,

where $\omega_{i t}$ is the original LFS sample weight that we have multiplied by monthly hours of work, following for instance DiNardo, Fortin, and Lemieux (1996), and Lemieux (2002). To ensure that the age-education-years of residence composition is the same for each occupation in periods 0 and 1 , we assign to each cell $c$ the same average weight as the cell at period 0 . This means including the sample share of cell $c$ in period 0 in the calculation of the corresponding reweighting factors. Thus, the reweighting factor of cell $c$ in occupation $j$ and period $t$ is defined as:

$\Psi_{c j t}=\eta_{c 0} / \eta_{c j t}$,

where $\eta_{c j t}$ corresponds to the observed share of cell $c$ (defined by a particular age-education-length of residence) in occupation $j$ in period $t$, and $\eta_{c 0}$ is the same share in period 0 . That is, the numerator stands for the counterfactual sample share of cell $c$ in occupation $j$ that we require to be identical for both periods.

We use the resulting counterfactual sample weights $\omega_{c j t}^{a}=\Psi_{c j t} \omega_{c j t}$ to estimate the individual wage distribution that would have arisen if the age-education composition for natives and age-education-length of residence composition for immigrants in each occupation had been constant over time.

\section{B.2 The alternative scenarios}

We measured the contribution of tasks' returns to between- and within-occupation wage changes under three alternative scenarios differing in $(i)$ the explanatory variables considered to estimate residual wages with the Mincer equation, and (ii) the sampling weights employed to estimate occupation-specific residual wage deciles used in the regression and to compute the between and within components.

- In the "Baseline" scenario, residual wages are obtained by regressing the log wage over standard variables in a Mincer equation, age $\times$ educ, and country of origin. Then, occupation-specific residual wage deciles are estimated using the LFS sampling weights.

- In the "Weight 1" scenario, residual wages for immigrants are obtained by regressing the log wage over age $\times$ educ $\times$ resid $^{47}$ and country of origin. Residual wage deciles are then obtained using counterfactual weights ensuring a constant composition of worker characteristics (age $\times$ educ $\times$ resid) by nativity group within occupations.

- In the "Weight 2" scenario, residual wage deciles are obtained using counterfactual weights ensuring a constant composition of worker characteristics (age $\times$ educ $\times$ resid) across nativity groups within

\footnotetext{
46 Borjas (2003) assumes that age of entry to the labor force is 16 for high school dropouts with no vocational education, 19 for high school dropouts with vocational education or high school graduates without vocational education, 21 for high school graduates with vocational education, 24 for those who completed non-university higher education and 25 for workers who hold a university degree. Ottaviano and Peri (2012) calculate years of potential experience under the assumption that high school dropouts enter the labor force at age 17, high school graduates enter at 19 , those with some university education enter at 21 , and people with a university degree enter at 23.

${ }^{47}$ The resid variable is defined for more than ten years of residence or less than ten years of residence.
} 
occupations: the age-education composition of natives in period 0 is taken as reference.

Additional estimates were performed without taking into account length of residence for immigrants and keeping age-education composition constant. These are not reported in the paper but are available upon request from the authors.

\section{Additional Figures}

\section{C.1 Immigrants and natives' wage dynamics at equal and constant composition}

Figure 8: Average yearly wage growth in relation to the 1994 median wage in the occupation when controlling for composition effects. French LFS 1994-2012

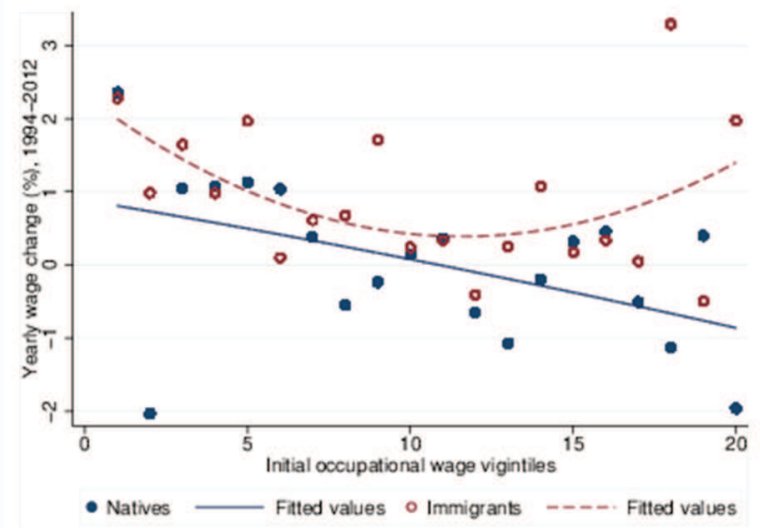

Notes: Occupations are ranked in the X-axis in ascending order according to their median real wage in 1994, computed on native full-time equivalent workers, and then gathered within occupational wage vigintiles. The Y-axisrepresents the average yearly real wage growth by vigintile over the period $1994-$ 2012. Age*education composition is kept constant across years and equal to that of natives in 1994. Length of residence for immigrants is kept constant across years and equal to that in 1994 .

\section{C.2 Worker sorting following changes in occupation-specific goods and services}

Figure 9: Wages and skill returns


\section{C.3 Variance decomposition analysis}

To assess how occupations impact the dynamics of the wage differentials between individuals, we propose a wage variance decomposition analysis for each nativity group. We first remove for each nativity group the proportion of total wage variance ("Total" line) due to observable individual characteristics, considering the residual wage variance ("Residual" line), i.e. the variance of residuals from the following wage equation:

$\ln w_{i n t}=\alpha_{n t}+\beta_{n t}$ age $\times$ educ $\times$ resid $_{i n t}+\gamma_{n c t}$ country $_{\text {inct }}+\tilde{w}_{\text {int }}$,

where $w_{i n t}$ stands for the hourly wage of an individual $i$ from nativity group $n$ (natives, immigrants) in year $t$, 
age $\times$ educ $\times$ resid $_{\text {int }}$ stands for the different individual cells (up to 72 for immigrants and 36 for natives) we define each year from the following groups : 9 age groups (from 15 to 60 years old using five-year intervals), 4 educational groups (less than Baccalaureate, Baccalaureate or equivalent, Baccalaureate plus two years, and higher degrees) and 2 length of residence intervals (less than 10 years, more than 10 years). country $y_{\text {inct }}$ contains a set of dummy variables for geographical origins of immigrants (a dummy for each of the 27 countries distinguished in the LFS). $\tilde{w}_{\text {int }}$ are the estimated residual wages that we then decompose into between- and within- occupation components by relating them to a full set of occupation dummies as follows:

$$
\tilde{w}_{\text {int }}=\theta_{\text {njt }} \text { occupation }_{\text {injt }}+v_{\text {int }}
$$

where occupation $_{\text {injt }}$ stands for the $j$-th occupational dummy variable. $v_{\text {int }}$ is the proportion of the first-stage wage residual that is not explained by differences across occupations but rather by unobserved differences across individuals working in the same occupations (i.e. skill endowments, skill returns, unobserved abilities or reservation wages). The within-occupation residual wage variance ("Within-occupation" line) is obtained by computing for each year and for each nativity group the variance of $v_{i}$, and represents the proportion of residual wage variance explained by wage disparities within occupations. Thus, the vertical distance between the residual wage variance and the within-occupation residual wage variance corresponds to the proportion of residual wage variance that is explained by differences between occupations, e.g. different task content and occupation- specific skill returns. In contrast, the vertical distance between the $\mathrm{x}$-axis and the within-occupation residual wage variance corresponds to the proportion of residual wage variance explained by differences across individuals employed in the same occupation.

Figure 10: Variance decomposition analysis by nativity group. France 1994-2012
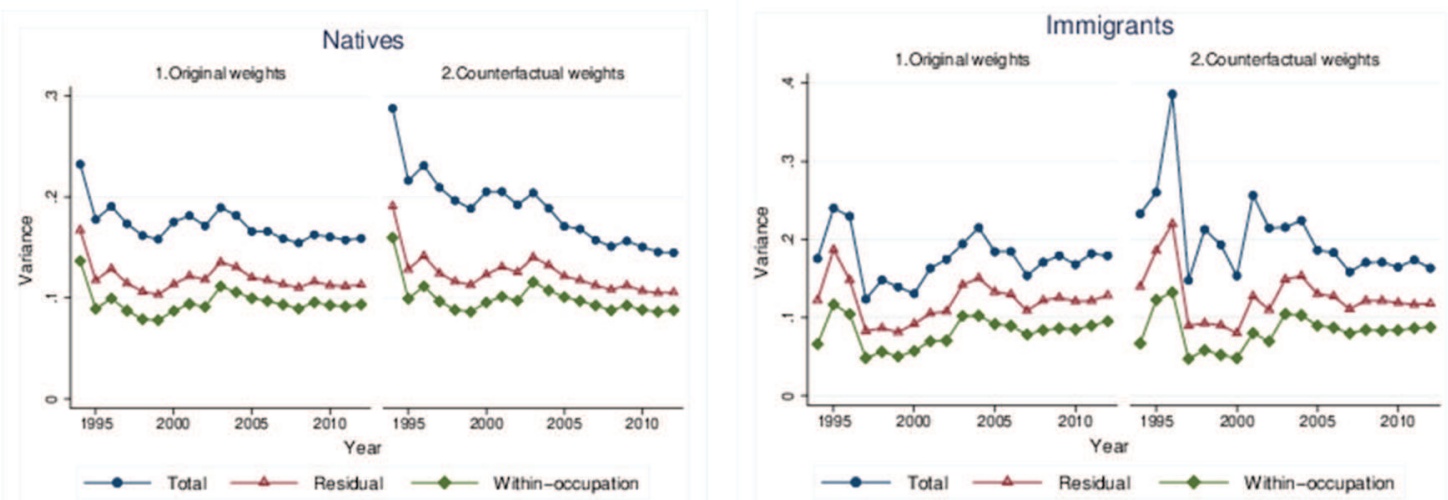

Notes: The vertical distance between the Total line and the Residual line corresponds to wage disparities explained by age, education, length of residence and country of origin differences. The vertical distance between the Residual line and the Within- occupation line corresponds to the proportion of residual wage variance explained by differences between occupations. The vertical distance between the X-axis and the Within-occupation line corresponds to the proportion of residual wage variance explained by wage disparities within occupations. In the panels "Original weights" we use the sample weights provided by the LFS. In the panels "Counterfactual weights" we reweight each nativity group so that the age-education-years of residence composition is constant over all years.

Wage differences within and between occupations continue to be predominant in total wage variance even after the mechanical effect from changes in the composition of observable characteristics on residual wages (i.e. composition effects) is removed by reweighting each nativity sample so as to obtain the same composition in terms of age, education and length of residence ${ }^{48}$ (see "Counterfactual weights" panels in Figure 10). Thus, quantitatively, occupations appear relevant as a unit of analysis of wage differentials between individuals and their evolutions over time, especially since the role of observable characteristics tends to decrease over time for both immigrants and natives (particularly under constant population composition).

\footnotetext{
${ }^{48}$ As explained in Appendix B, we reweight our sample by $\omega_{c t}^{a}=\Psi_{c t} \omega_{c t}$, where $\omega_{c t}$ is the original sample weight of cell $c$ and period $t$ and $\Psi_{c t}$ is the reweighting factor we estimate for each cell $c$ at period $t$. More precisely, $\Psi_{c t}=\eta_{c} / \eta_{c t}$ where $\eta_{c}$ is the share of workers (natives or immigrants) in the ageeducation cell c over the whole considered period (1994-2012) and $\eta_{c t}$ is the share of workers (natives or immigrants) in the age-education cell $c$ in period $t$.
} 


\section{C.4 Between- and within-occupation wage changes}

Consistent with our conceptual framework, we find a positive correlation between the two components of the price effect: higher values of the between coefficient are associated with higher values of the within coefficient, so that $\operatorname{Cov}\left(a_{j}, b_{j}\right)>0$, as predicted by our Roy-type model.

Figure 11: Between- and within-occupation coefficients using LFS weights.
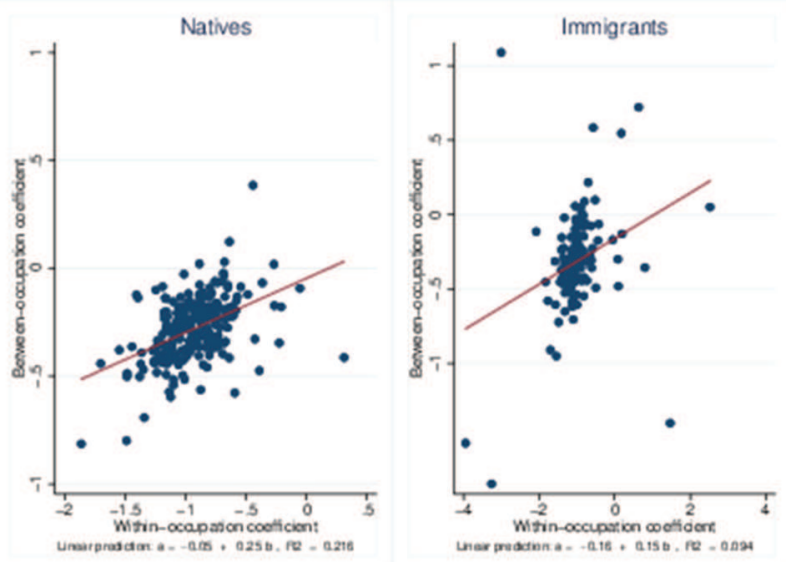

Notes: Natives' residual wages are computed including in the wage equation a full set of age*education dummies while immigrants' residual wages are computed including in the wage equation a full set of age*education*length of residence dummies and 27 country of origin dummies. The between - and withinoccupation coefficients are computed considering 10 deciles. Composition effects are not controlled for.

Figure 12: Between- and within-occupation coefficients with constant labor force composition.
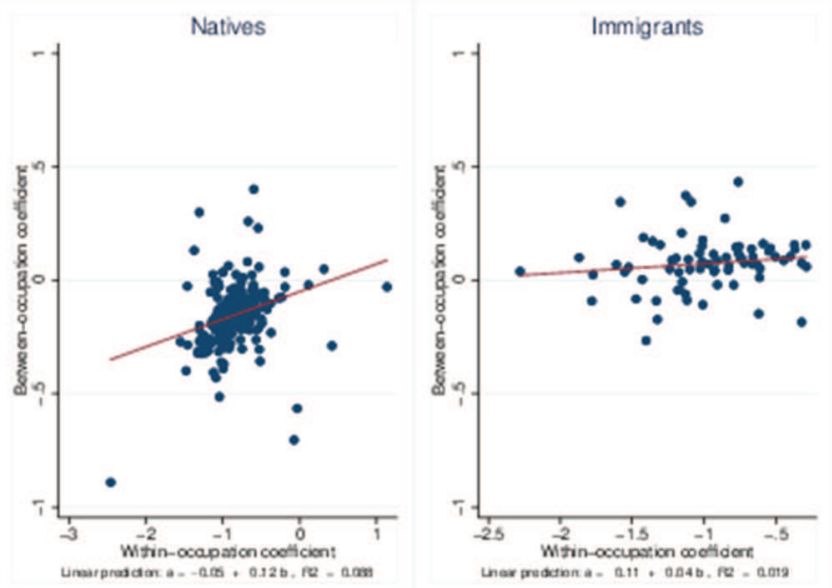

Notes: Natives' residual wages are computed including in the wage equation a full set of age*education dummies while immigrants' residual wages are computed including in the wage equation a full set of age*education*length of residence dummies and 27 country of origin dummies. The between- and withinoccupation coefficients are computed considering 9 wage deciles. Age*education composition within occupations is kept constant and equal to that of natives in period 1994-1996 for both immigrants and natives. For immigrants, length of residence composition is also kept constant and equal to that observed in 1994-1996. 
Figure 13: Between- and within-occupation wage changes: Natives vs. Immigrants, LFS weights.

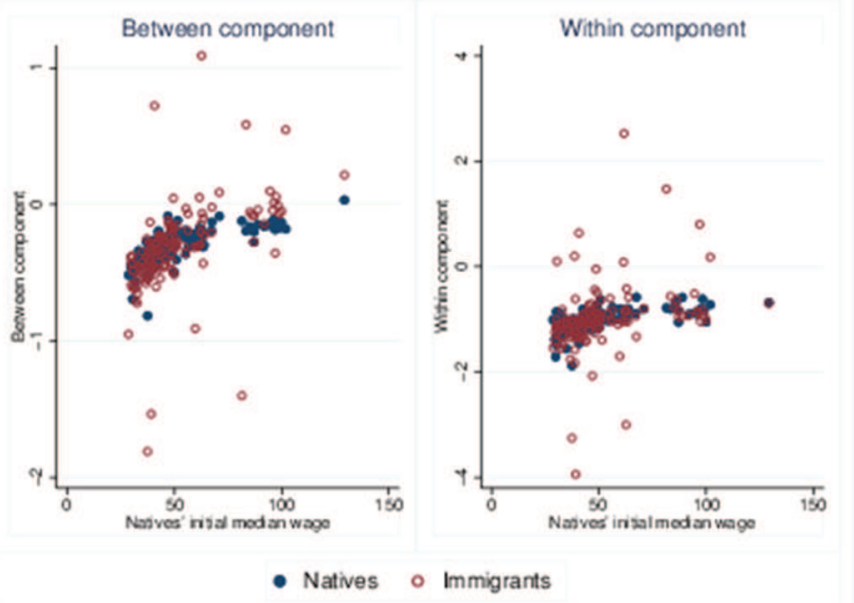

Notes: Natives' residual wages are computed including in the wage equation a full set of age*education dummies while immigrants' residual wages are computed including in the wage equation a full set of age*education*length of residence dummies and 27 country of origin dummies. The between- and withinoccupation coefficients are computed considering 10 deciles. The X-axis stands for the occupational residual wage in period 1994-96 (common support for natives and immigrants). Composition effects are not controlled for.

\section{Estimations}

Table 5: Immigrant effect on between- and within-occupation wage changes, from 1994-96 to 2010-12. Pooled sample.

Dependent variables: Between- and within-occupation wage changes

\begin{tabular}{|c|c|c|c|c|c|c|}
\hline \multirow[b]{2}{*}{ Scenarios } & \multicolumn{3}{|c|}{ Between-occupation wage change } & \multicolumn{3}{|c|}{ Within-occupation wage change } \\
\hline & Baseline & Weight 1 & Weight 2 & Baseline & Weight 1 & Weight 2 \\
\hline & (1) & (2) & (3) & (4) & (5) & (6) \\
\hline \multirow[t]{2}{*}{ Immigrant } & $0.271 * * *$ & $0.434 * * *$ & $0.259 * * *$ & $-0.0855^{* *}$ & $0.249 * * *$ & -0.0405 \\
\hline & $(0.0202)$ & $(0.0208)$ & $(0.0160)$ & $(0.0393)$ & $(0.0442)$ & $(0.0439)$ \\
\hline \multicolumn{7}{|l|}{ Population composition constant } \\
\hline within group & NO & YES & YES & NO & YES & YES \\
\hline within and across groups & NO & NO & YES & NO & NO & YES \\
\hline Control for length of residence & NO & YES & YES & NO & YES & YES \\
\hline Observations & 250 & 164 & 146 & 250 & 164 & 146 \\
\hline R-squared & 0.371 & 0.715 & 0.556 & 0.014 & 0.124 & 0.004 \\
\hline
\end{tabular}

Notes: Robust standard errors in parentheses. Statistical significance: $* * * p<0.01, * * p<0.05, * p<0.1$. In all regressions we control for an occupationspecific labor demand shift index (see text for details). Regressions are weighted using the initial period of employment in the occupation of the corresponding nativity group. In all columns, natives' wage residuals are computed including in the wage equation a full set of age*education dummies. In columns (1) and (4) immigrants' wage residuals are computed including in the wage equation a full set of age*education dummies and 27 country of origin dummies. In columns (2), (3), (5) and (6) wage residuals for immigrants are computed including a full set of dummies for age*educ*length of residence categories. In scenario Weight 1 , population composition within occupations is kept constant, as in the baseline for each nativity group. In Weight 2 , population composition within occupations is kept constant and the baseline population composition of natives is applied to both immigrants and natives. Control for population composition effects includes immigrants' length of residence.

Table 6: Immigrant and task contribution to between- and within-occupation wage changes, from 1994-96 to 2010- 
Dependent variables: Between- and within-occupation wage changes

\begin{tabular}{l|ccc|ccc}
\hline \hline \multirow{3}{*}{ Scenarios } & \multicolumn{3}{|c|}{ Between-occupation wage change } & \multicolumn{3}{c}{ Within-occupation wage change } \\
& Baseline & Weight 1 & Weight 2 & Baseline & Weight 1 & Weight 2 \\
\hline \multirow{4}{*}{ Immigrant } & $(1)$ & $(2)$ & $(3)$ & $(4)$ & $(5)$ & $(6)$ \\
& $0.278^{* * *}$ & $0.439^{* * *}$ & $0.261^{* * *}$ & $-0.0661^{*}$ & $0.262^{* * *}$ & -0.0316 \\
Non-routine abstract & $(0.0170)$ & $(0.0205)$ & $(0.0134)$ & $(0.0378)$ & $(0.0458)$ & $(0.0459)$ \\
& $0.175^{* * *}$ & $0.132^{* * *}$ & $0.0740^{*}$ & $0.344^{* * *}$ & $0.394^{* * *}$ & $0.295^{* *}$ \\
Routine & $(0.0431)$ & $(0.0458)$ & $(0.0397)$ & $(0.100)$ & $(0.131)$ & $(0.137)$ \\
& $-0.277^{* * *}$ & $-0.149^{* * *}$ & $-0.169^{* * *}$ & $-0.524^{* * *}$ & $-0.292^{*}$ & $-0.403^{* * * *}$ \\
Non-routine manual & $(0.0598)$ & $(0.0529)$ & $(0.0501)$ & $(0.141)$ & $(0.158)$ & $(0.152)$ \\
& $0.311^{* * *}$ & $0.192^{* * *}$ & $0.259^{* * *}$ & $0.225^{* *}$ & 0.119 & $0.296^{* * *}$ \\
Population composition constant & $(0.0532)$ & $(0.0482)$ & $(0.0460)$ & $(0.102)$ & $(0.115)$ & $(0.101)$ \\
$\quad$ within group & & & & & & \\
$\quad$ within and across groups & NO & YES & YES & NO & YES & YES \\
Control for length of residence & NO & NO & YES & NO & NO & YES \\
Observations & NO & YES & YES & NO & YES & YES \\
R-squared & 248 & 162 & 144 & 248 & 162 & 144 \\
& 0.526 & 0.766 & 0.685 & 0.183 & 0.229 & 0.110 \\
\hline
\end{tabular}

Notes: Robust standard errors in parentheses. Statistical significance: $* * * p<0.01, * * p<0.05, * p<0.1$. In all regressions we control for an occupationspecific labor demand shift index (see text for details). Regressions are weighted using the initial period of employment in the occupation of the corresponding nativity group. In all columns, natives' wage residuals are computed including in the wage equation a full set of age*education dummies. In columns (1) and (4) immigrants' wage residuals are computed including in the wage equation a full set of age*education dummies and 27 country of origin dummies. In columns (2), (3), (5) and (6) wage residuals for immigrants are computed including a full set of dummies for age*educ*length of residence categories. In scenario Weight 1 , population composition within occupations is kept constant, as in the baseline for each nativity group. In Weight 2 , population composition within occupations is kept constant and the baseline population composition of natives is applied to both immigrants and natives. Control for population composition effects includes immigrants' length of residence.

Table 7: Task contribution to the estimated between- and within-occupation wage change differential between natives and immigrants, from 1994-96 to 2010-12.

Dependent variables: estimated differential in between- and within-occupation wage changes

\begin{tabular}{|c|c|c|c|c|c|c|}
\hline \multirow[b]{2}{*}{ Scenarios } & \multicolumn{3}{|c|}{ Between-occupation wage change } & \multicolumn{3}{|c|}{ Within-occupation wage change } \\
\hline & Baseline & Weight 1 & Weight 2 & Baseline & Weight 1 & Weight 2 \\
\hline & (1) & (2) & (3) & (4) & (5) & (6) \\
\hline \multirow[t]{2}{*}{ Non-routine abstract } & $0.135 * *$ & 0.133 & 0.0892 & -0.119 & -0.321 & 0.110 \\
\hline & $(0.0671)$ & $(0.172)$ & $(0.0561)$ & $(0.178)$ & $(0.265)$ & $(0.284)$ \\
\hline \multirow[t]{2}{*}{ Routine } & -0.0909 & 0.123 & 0.0291 & $0.337^{*}$ & $0.692 * *$ & 0.226 \\
\hline & $(0.0896)$ & $(0.162)$ & $(0.0736)$ & $(0.202)$ & $(0.309)$ & $(0.315)$ \\
\hline \multirow[t]{2}{*}{ Non-routine manual } & 0.0661 & -0.193 & -0.0873 & -0.277 & $-1.015^{* * *}$ & $-0.598 *$ \\
\hline & $(0.0817)$ & $(0.201)$ & $(0.0638)$ & $(0.186)$ & $(0.334)$ & $(0.320)$ \\
\hline \multicolumn{7}{|l|}{ Population composition constant } \\
\hline within group & NO & YES & YES & NO & YES & YES \\
\hline within and across groups & NO & NO & YES & NO & NO & YES \\
\hline Control for length of residence & NO & YES & YES & NO & YES & YES \\
\hline Observations & 124 & 81 & 72 & 124 & 81 & 72 \\
\hline R-squared & 0.032 & 0.038 & 0.035 & 0.018 & 0.142 & 0.113 \\
\hline
\end{tabular}

Notes: Robust standard errors in parentheses. Statistical significance: $* * * p<0.01, * * p<0.05, * p<0.1$. In all regressions we control for an occupationspecific labor demand shift index (see text for details). Regressions are weighted using the initial period of employment in the occupation of the corresponding nativity group. In all columns, natives' wage residuals are computed including in the wage equation a full set of age*education dummies. In columns (1) and (4) immigrants' wage residuals are computed including in the wage equation a full set of age*education dummies and 27 country of origin dummies. In columns (2), (3), (5) and (6) wage residuals for immigrants are computed including a full set of dummies for age*educ*length of residence categories. In scenario Weight 1 population composition within occupations is kept constant as in the baseline for each nativity group. In Weight 2 , population composition within occupations is kept constant, and the baseline population composition of natives is applied to both immigrants and natives. Control for population composition effects includes immigrants' length of residence. 